\title{
1 The Tasiast Deposit, Mauritania
}

2

3

4

5

6

\section{Kyle HERON}

Department of Geology, School of Natural Sciences, Trinity College, Dublin 2, Ireland Mark JESSELL

Laboratoire GET, Université Toulouse 3 Paul Sabatier, IRD, CNRS UMR 5563, Observatoire MidiPyrénées, 31400 Toulouse, France and Centre for Exploration Targeting, The University of Western Australia, 35 Stirling Highway, Crawley, WA, 6009, Australia

\section{Keith BENN}

Terracognita Geological Consulting Inc., P. O. Box 100, 4874 St. Clair Parkway, Port Lambton, ON N0P 2B0, Canada

\section{Esther HARRIS}

Mineral Exploration Consultant, 96 Marlow St, Wembley, WA, 6014, Australia

\section{Quentin G. CROWLEY}

Department of Geology, School of Natural Sciences, Trinity College, Dublin 2, Ireland

\section{ABSTRACT}

The Tasiast gold deposits are hosted within Mesoarchean rocks of the Aouéouat greenstone belt, Mauritania. The Tasiast Mine consists of two deposits hosted within distinctly different rock types, both situated within the hanging wall of the west-vergent Tasiast thrust. The Piment deposits are hosted within metasedimentary rocks including metaturbidites and banded iron formation where the main mineral association consists of magnetite-quartz-pyrrhotite \pm actinolite \pm garnet \pm biotite. Gold is associated with silica flooding and sulphide replacement of magnetite in the turbidites and in the banded iron formation units. The West Branch deposit is hosted within meta-igneous rocks, mainly diorites and quartz diorites that lie stratigraphically below host rocks of the Piment deposits. Most of the gold mineralisation at West Branch is hosted by quartz-carbonate veins within the sheared and hydrothermally altered meta-diorites that constitute the Greenschist Zone. At Tasiast, gold mineralisation has been defined over a strike length $>10 \mathrm{~km}$ and to vertical depths of $740 \mathrm{~m}$. All of the significant mineralised bodies defined to date dip moderately to steeply $\left(45^{\circ}\right.$ to $\left.70^{\circ}\right)$ to the east and have a south-southeasterly plunge. Gold deposits on the Tasiast trend are associated with second order shear zones that are splays cutting the hanging wall block of the Tasiast thrust. An age of $2839 \pm 36$ Ma obtained from the hydrothermal overgrowth on zircons from a quartz vein is interpreted to represent the age of mineralisation.

Key words: Tasiast, Gold, Mauritania, BIF, Zircon geochronology 


\section{Introduction}

There are 5 principal geological domains within the borders of Mauritania (Fig. 1a). The Reguibat Shield to the north of the country, hosts Archean and Palaeoproterozoic metamorphic sequences and granites that form the northwestern limit of the West African Craton (Ennih and Liegeois, 2008; Key et al., 2008). Further south the craton margin coincides with the Mauritanides, a Hercynian tectonic belt that consists of Neoproterozoic and Palaeozoic metamorphosed sediments and volcanoclastic formations and that also includes parts of the basement (Villeneuve, 2008). To the east of the Mauritanide belt lies the vast Mesoproterozoic (Teal and Kah, 2005; Rooney et al., 2010) to Palaeozoic Taoudeni basin. Finally to the West of the Mauritanides lies the northern limit of the MauritaniaSenegal-Gambia-Bissau-Conarky Basin, which is a Mesozoic-Cenozoic continental margin basin overlying a Palaeozoic (and probably Archean) basement.

Mauritania is a significant source of copper, gold, and iron ore and was the second ranked exporter and producer of iron ore in Africa, after South Africa, in 2012. In addition to iron ore, Mauritania produces cement, copper, crude oil, gold, gypsum, quartz, salt, and steel (Taib, 2012). The Tasiast gold deposit (location coordinates: $15.5124^{\circ} \mathrm{W}, 20.5786^{\circ} \mathrm{N}$ ) is a $>10$ million ounce deposit located within the southwestern part of the Reguibat Shield, in the administrative region (Wilaya) of Inchiri, $250 \mathrm{~km}$ northeast of the capital Nouakchott.

Before discovery of the Tasiast deposit, the area had been subject to three regional exploration programs during the 1960s and 1970s with various non-gold targets as summarised in Table 1 (Stuart, 2010). The area was identified as being anomalous in gold during the first regional-scale geological mapping and geochemical sampling program of the European Development Fund project undertaken between 1993 and 1996 by the Bureau de Recherches Géologiques et Minières (BRGM) and the Office Mauritanien de Recherche Géologique (OMRG). The primary mission of the project was to locate new mineral indices of potential economic importance in the Tasiast area. More detailed soil sampling followed, resulting in the identification of a series of geochemical anomalies which were later tested by manual trenching. One of the soil geochemical anomalies, then called the C6-9 anomaly, eventually became the main Tasiast prospect (Stuart, 2010).

Exploration programs were conducted by a series of companies, beginning with Normandy La Source Development in 1996 who defined two principal areas of gold mineralisation within the Tasiast prospect (Mining Journal, 2006). Commercial production began in January 2008 when the mine was owned and operated by Red Back Mining B.V. (Stuart, 2010). The Tasiast mine is currently 100\% owned and operated by the Kinross Gold Corporation. Kinross currently estimates the gold resource to be 12.8 million ounces at an average grade of $1.5 \mathrm{~g} / \mathrm{t}$ (Table 2). In 2013, $2.5 \mathrm{Mt}$ ore yielding 144,000 oz Au at a grade of $1.96 \mathrm{~g} / \mathrm{t}$ in addition to $104,000 \mathrm{oz}$ of dump leach gold for a total of 248,000 oz Au were produced (Table 3) (Sims, 2014).

\section{Geological overview}


The Tasiast gold deposit is located within one of three principal Precambrian greenstone belts that form part of the Tasiast-Tijirit Terrane located in the western part of the Reguibat Shield (Fig. 1a). The Reguibat Shield consists of a series of west to east accreted, north-south trending Archean and Paleoproterozoic metavolcano-sedimentary belts and domal basement gneiss complexes. The majority of rocks that have been dated in the Tasiast-Tijirit Terrane have been gneiss, TTG and granite samples, and are all between 2.97 Ga and 2.91 Ga in age (Chardon 1997, Key et al., 2008, Schofield et al., 2012; Gärtner et al., 2013, Montero et al., 2014). There have been two older TTG samples dated in the north of the region between 3.03 Ga and 3.01 Ga (Gärtner et al., 2013, Montero et al., 2014). The single other lithology to be dated in the region is a felsic volcanic obtained from drill core at the Tasiast deposit, which yielded an age of $2.97 \mathrm{Ga}$ (Key et. al., 2008), which is currently the best constraint for the age of the host rocks at Tasiast. Although no crystallisation events older than $3.03 \mathrm{Ga}$ are preserved in the Tasiast-Tijirit Terrane, whole rock Nd $T_{\text {DM }}$ ages ranging from 3.60 Ga - 2.95 Ga (Chardon 1997, Key et al., 2008, Montero et al., 2014) suggest a contribution of older crustal material was involved in its creation.

The Aouéouat greenstone belt lies on the edge of one of a series of ENE oriented long-wavelength gravity and magnetic anomalies (Fig. 1b; Jessell et al., 2015). The Tasiast deposit is hosted within the north-south trending Aouéouat greenstone belt that is continuous for about $75 \mathrm{~km}$ strike length and shows as a series of high magnitude parallel anomalies in airborne magnetic data (Fig. 2b). The mine geology is characterized by a mafic to felsic meta-igneous succession, overlain by the remains of a sedimentary basin (Fig. 2a) that formed during rifting in a sinistral transtensional tectonic regime (Kruse, 2013). The preserved sedimentary stratigraphy includes abundant greywackes, siltstones, turbidite sequences and minor amounts of silica facies and possibly some oxide facies banded iron formations (BIF). The siliciclastic sedimentary rocks contain detritus derived from gneissic basement rocks as well as from younger volcanic and intrusive rocks that formed prior to the rifting event.

Gold mineralisation formed during the approximately E-W bulk shortening event that accompanied inversion of the Tasiast sedimentary basin (Fig. 3). That deformation resulted in tight to isoclinal, upright to overturned folds, thrusting and transcurrent shearing throughout the Aouéouat belt (Fig. 4a). According to the present understanding the Tasiast deposits were formed during that single, possibly transpressive tectonic event. In all the Piment deposits, gold is associated with silica flooding and sulfidation of magnetite. At West Branch, the gold is hosted by quartz-carbonate veins that are folded and locally transposed parallel to the principal foliation that is axial planar to the folds. Several families of northeast and northwest striking brittle faults crosscut the folds and locally offset geological units.

The rocks of the Aouéouat belt, including the host rocks of the Piment and West Branch deposits, preserve upper greenschist to lower amphibolite peak metamorphic mineral assemblages, and a younger supergene alteration history. Mineral parageneses including cordierite and andalusite indicative of HTLP peak metamorphism have been locally identified within metasedimentary units and may be 
111 associated with the emplacement of intrusive bodies of diorite and granodiorite compositions. Gold

112 deposition occurred under middle greenschist post-peak metamorphic conditions as indicated by the

113 presence of retrograde mineral assemblages including chlorite that are associated with mineralised veins

114 and shear zones.

\section{Gold mineralisation}

The Tasiast Mine consists of two deposits hosted within distinctly different rock types. Both deposits are situated within the hanging wall block of the west vergent Tasiast thrust.

The Piment deposits are currently exploited as three main pits (North, Central and South) (Fig. 3) and are all hosted within metasedimentary rocks including metaturbidites and minor banded iron formation. Gold is associated with silicification and sulphide replacement of magnetite as observed within the turbidites and the banded iron formation units. In the Piment deposits the iron rich rocks represented a chemcially reactive host for gold mineralization. The alteration mineral assemblage is principally associated with brittle-ductile splay thrusts that branch off the Tasiast thrust.

i. The West Branch deposit hosts the bulk of the gold at Tasiast. It is hosted within meta-igneous rocks, predominantly diorites and quartz diorites that lie stratigraphically below the host rocks of the Piment deposits. The dioritic host rocks are situated within the core of an overturned antiformal fold and are bounded above and below by felsic metavolcanic rocks. The diorites are thought to have been the preferred host for gold because they represented a less ductile lithology that the enveloping felsic rocks, such that they efficiently localized high strains within shear zones that channeled fluids and that acted as structural traps. At West Branch several facies of veins are recognized within the so-called Greenschist Zone and include the following (in order of paragenesis):Early milky white quartz veins that are commonly tightly to isoclinally folded, and boudinaged at a low angle to the foliation.

ii. Quartz-albite-tourmaline veins that are also boudinaged at low angles to foliation.

iii. Greenish gray to translucent quartz \pm native gold veins with a silica selvedge at low angles to foliation.

iv. Quartz-amphibole-biotite-carbonate-pyrite \pm garnet veins at low angles to the foliation.

v. Quartz-carbonate-biotite \pm actinolite \pm pyrite \pm pyrrhotite \pm tourmaline \pm magnetite \pm garnet veins that crosscut foliation at a high-angle.

The first four vein facies listed above are clearly syn-orogenic, probably having formed in extensional or shear fractures and were subsequently folded, boudinaged and locally transposed into the folation plane, or nearly so, during progressive deformation. Facies (i), (ii) and (iii) are observed to be cross-cut by veinlets of facies (iv) and visible gold is commonly associated with the carbonate-pyrite \pm biotite rich veinlets. Facies (v) may be late orogenic, as those veins tend to be planar and undeformed to weakly deformed. The same facies of veins have been documented at satellite exploration targets along the Tasiast trend. 
Metallic mineralogy within the Greenschist Zone is dominated by pyrrhotite, pyrite and native gold that occur as vein infill and alteration spots along the foliation, mainly in proximity to the veins.

150 Pyrrhotite and pyrite occur together in many places but in variable ratios, with pyrrhotite being the predominant sulfide. Zones of pyrite-only and pyrrhotite-only mineralisation are rare. Blake (2011a, b in Sims, 2014) studied the nature, grain size and mode of occurrence of native gold grains in seven composites from two drill holes that intersected Greenschist Zone-style mineralisation. Results from the study concluded that the volume of coarse $(>100 \mu \mathrm{m})$ Au grains account for the majority of contained $\mathrm{Au}$ and greater than $60 \%$ of grains occur in the liberated form and a lesser portion associated with gangue minerals and micrometre grains detected in slimes. At Piment the minerals of interest include native gold, pyrrhotite and pyrite.

Other sulphide minerals are recognized at both deposits in minor to trace abundances. These include electrum, chalcopyrite, arsenopyrite, sphalerite, galena, covellite, pentlandite and petzite.

\section{Ore body characteristics}

162

Gold mineralisation at the West Branch and Piment deposits has been defined over a strike length of about $10 \mathrm{~km}$ and to vertical depths of $740 \mathrm{~m}$. Other mineralised exploration targets extend the strike length of the Tasiast camp several kilometres to the north and south. The deposits defined to date dip moderately to steeply $\left(45^{\circ}\right.$ to $\left.70^{\circ}\right)$ to the east and have a south-southeasterly plunge; at some satellite exploration targets the mineralisation dips steeply to the west.

Piment mineralisation is largely hosted along splay faults and within the adjacent altered and veined iron formation and turbiditic units. Individual mineralised shoots are continuous over $300 \mathrm{~m}$ and to vertical depths of at least $260 \mathrm{~m}$.

Most of the gold mineralisation at West Branch is hosted by quartz-carbonate veins in hydrothermally altered meta-diorites (Greenschist Zone, Fig. 4b). The meta-diorites are enveloped by a felsite unit that occurs on the footwall and hanging wall sides of the Greenschist zone, defining an overturned antiformal fold in the hanging wall of the Tasiast thrust. The Greenschist Zone is characterized by intervals of mineralisation averaging $40 \mathrm{~m}$ to $100 \mathrm{~m}$ in thickness. Individual shoots are

\section{Geometric and kinematic controls}

Gold mineralisation is associated with shear zones, quartz-veining (mainly at West Branch) and silica-flooding and sulphidation of magnetite (mainly at Piment, Fig. 4c). Gold deposits on the Tasiast trend are spatially associated with second order shear zones that are splay thrusts cutting the hanging wall block of the Tasiast thrust. Coarse visible gold is common within the quartz-carbonate veins (Fig. $4 d)$. 
Thrusting and tight to isoclinal folding has resulted in thickening of the stratigraphic package at Tasiast. The dominant foliation in the mine sequence is moderately to steeply east-dipping $\left(45^{\circ}-70^{\circ}\right)$. Individual shear zones are typically $0.5 \mathrm{~m}$ to $10 \mathrm{~m}$ thick and are characterized by planar-laminated foliation with mylonitic textures locally observed. The shearing is commonly localised at contacts of lithologic units. The current structural interpretation of the mine area suggests that mineralisation is associated with second order shear zones that formed in the tightly to isoclinally folded rocks within the hanging wall of the west-vergent Tasiast thrust. The shear zones developed preferentially along the limbs of, and within the cores of very tight to isoclinal folds. Vein sets occur subparallel and oblique to foliation in styles that include boudinaged, buckled and planar.

\section{Alteration}

196

The following hydrothermal alteration and mineralisation history (Japan International Cooperation Agency (JICA)/OMRG, 2005) is thought to be a down-temperature time sequence, based on mineralogy and fluid inclusion analysis:

i. Tungsten mineralisation suggests a temperature maximum of about $280^{\circ} \mathrm{C}$. The salinity of the

\section{Age of Mineralisation}

Previous studies attempting to date the age of Tasiast mineralisation have relied on K-Ar dating of low potassium sericite, which gave an age of $1.9 \mathrm{Ga}$ from a white argillized zone at the surface (Marutani et al., 2005). Dating of two distinct morphological types of hydrothermal monazite and xenotime from the Guelb Moghrein copper deposit yielded in situ U-Pb ages of $2492 \pm 9$ and $1742 \pm 12$ Ma respectively (Meyer et al., 2006) so a Meso-Proterozoic remobilisation remains a possibility in this part of the Reguibat Shield. 
Apart from the results above, which do not seem to correlate with significant tectonic or magmatic activity in this region, there have been no previous attempts to directly date mineralisation at the Tasiast deposit. In order to address this we collected four samples of mineralised quartz veins from the Tasiast Mine and from several nearby exploration targets within the Aouéouat belt; three samples from drill core and one from an exploration trench. Three of these samples represent exploration target rocks, with the fourth being from the operational West Branch deposit. The primary purpose was to extract any minerals that could be used to date the formation of the quartz veins with a focus on hydrothermal zircon, monazite or xenotime. Zircon was separated from three of the four quartz veins, with the West Branch vein the only sample returning no zircons. Neither monazite nor xenotime were recovered from any of the samples.

Samples were crushed and zircons separated using standard techniques (Gemini water table, Frantz magnetic separation, and MI heavy-liquid separation), mounted in 1 inch diameter epoxy resin mounts, and polished to expose a near-equatorial section through the crystals. Analysis was carried out at the Geology Department, Trinity College Dublin, using Q-LA-ICP-MS (Thermo Scientific iCAP Qs, Photon Machines 193 nm ArF Excimer laser; see Crowley et al. (2014) for operating conditions). Zircon 91500 (Wiedenbeck et al., 1995) was used as the primary standard, with Plešovice (Sláma et al., 2008) and Temora (Black et al., 2003) as secondary standards. The VizualAge data reduction scheme (Petrus and Kamber, 2012) within Iolite (Paton et al., 2011) was used to process data and Isoplot 4.15 (Ludwig, 2003) was used for data plotting. It is worth noting a large proportion of zircons analysed are discordant in nature, exhibiting varying degrees of Pb-loss. This is not unusual in Archean and Proterozoic terranes, and has been apparent in previous studies on the Tasiast-Tijirit Terrane (e.g. Key et al., 2008, Gärtner et al., 2013). The results of U-Pb dating from the three quartz veins containing zircon are presented below, and in Supplementary Material Table 1. TSUPB015, Quartz-Carbonate Vein (Drill Collar Location 446500, 2282415 UTM WGS84 Zone 28Q)

TSUPB015 is a sample of drill core from a hole located $5 \mathrm{~km}$ north of the Piment deposits in target C6.7 and it yielded 43 zircons (Fig. 5a). The vein includes facies (iii) cross-cut by facies (iv). CLimages of the zircons show oscillatory zoning in most indicating they are igneous in nature, with metamict cores present in some (Fig. 6a). The zircons are therefore almost certainly xenocrystic. A number of zircons possess an extremely thin $(<10 \mu \mathrm{m})$ overgrowth seen by the dark CL rim surrounding the zircon on all sides (Fig. 6a), interpreted as hydrothermal in origin. Of the 43 zircon analyses, 15 were $<10 \%$ discordant, with Concordia ages of $3037 \pm 29$ Ma and $2946 \pm 26$ Ma obtained from timeresolved components of these least discordant analyses. A further two analyses overlapping with Concordia were obtained from this sample, with Concordia ages of $2819 \pm 19$ and $2695 \pm 18$ Ma, the latter of which is attributed to Pb-loss (Fig. 7a). TSUPB016, Quartz-Carbonate Vein (Drill Collar Location 4502502273595 UTM WGS84 Zone 28Q) C6.12 and yielded 48 zircons (Fig. 5b). The vein is of the tourmaline bearing facies (ii). CL-images 
show oscillatory zoning again with some metamict cores indicating these too are xenocrystic, however none show evidence of hydrothermal overgrowths (Fig. 6b). This is confirmed by the U-Pb data, with the 14 analyses $<10 \%$ discordant containing one concordant population at $2953 \pm 11 \mathrm{Ma}$ (Fig. 7b), and a total range of ${ }^{207} \mathrm{~Pb} /{ }^{206} \mathrm{~Pb}$ ages of c. $3080-2945 \mathrm{Ma}$ (Fig. 7c). TSUPB026, Quartz-Carbonate Vein (Outcrop Location 4458492284695 UTM WGS84 Zone 28Q)

TSUPB026 was collected as a field sample of a quartz vein from an exploration trench in the Fennec target, $10 \mathrm{~km}$ north of the Piment deposits (Fig. 4e, 5c). The sample exhibited strong signs of weathering, breaking apart where transected by thin carbonate veinlets. The quartz itself however remained intact. The vein includes facies (iii) cross-cut by facies (iv). This sample, partially due to the ability to obtain a larger volume of rock than from drill core, yielded ample zircon, and so an initial set of 104 grains were analysed. CL-images show igneous zircon with oscillatory zoning, some with more complex zoning, and a number possessing cores (Fig. 6c). All zircons from this sample had an obvious, generally $<10 \mu$ thick, overgrowth which again has been interpreted as hydrothermal in origin. The entire population gave an upper-intercept age of $2950 \pm 11 \mathrm{Ma}$, with six zircons $<10 \%$ discordant giving an upper intercept age of $2958 \mathrm{Ma} \pm 14 \mathrm{Ma}$ (MSWD $=0.92$ ) which is the preferred age for this sample (Figs. 7d \& 7e).

Due to the ubiquitous presence of hydrothermal overgrowths on the zircons extracted from this sample, a second set of ten zircons were hand-picked, pre-treated in dilute $\mathrm{HNO}_{3}$, and mounted on double-sided sticky tape without polishing. The exterior crystal faces were then ablated in two-second increments in an attempt to sample only the hydrothermal overgrowths. Five of the ten analyses exhibited extreme $\mathrm{Pb}$-loss resulting in errors $>140 \mathrm{Ma}$, which was not unexpected, since the rim of a zircon is the most likely part of a crystal to be affected by Pb-loss (Krogh, 1982). Three analyses did not produce any meaningful data and one sample gave a similar age to those obtained above, highlighting the lack of an overgrowth. This left one analysis providing usable data. An upper-intercept age of the two-second increments gave an age of $2839 \pm 36 \mathrm{Ma}$ (Fig. 7f).

The ages between c. 3060 and 2945 Ma obtained from all three quartz veins are interpreted as xenocrystic inherited zircons from neighbouring country rocks, or from deeper unexposed rock, and so provide a window on the ages of rocks present in the Aouéouat stratigraphy. Most of these ages overlap within error of previous ages obtained from the Tasiast-Tijirit Terrane gneiss and TTG rocks (Chardon 1997, Key et al., 2008, Gärtner et al., 2013, Montero et al., 2014) which confirms this interpretation. The minor older component, up to $3080 \mathrm{Ma}$ is within error of zircon $\mathrm{T}_{\mathrm{DM}} \mathrm{Hf}$ model ages (c. 3080 to $3030 \mathrm{Ma}$ ) calculated from c. 2950 to 2910 Ma granitic and TTG intrusions in the Tasiast-Tijirit Terrane (Key et al., 2008). The $2839 \pm 36$ Ma age obtained from the hydrothermal overgrowth from the Fennec sample is within error of a concordant age obtained from C6.7 (2819 $\pm 19 \mathrm{Ma})$. The dated vein is of a known visible gold bearing generation. This age is interpreted as the crystallisation age of the hydrothermal quartz veins, and therefore the mineralisation age of the Tasiast deposit. 


\section{Summary}

297

298 The Tasiast gold deposit is situated on the flank of a long-wavelength gravity ENE oriented gravity 299

300

301

302

303

304

305

306

307

308

309

310

311

312

313

314

315

316

317 high and a north-south oriented BIF which appears clearly in regional aeromagnetic data. The deposit mineralisation is focused in splay shears off the west-vergent Tasiast thrust and is associated with an alteration sequence interpreted to show a down-temperature evolution with time. Mineralization is controlled by both chemical traps (especially at the Piment deposits) and structural traps (shear zones),, epigenetic in style and was coincident with early stages of post-peak metamorphic retrograde greenschist P-T conditions. An age of $2839 \pm 36$ Ma obtained from the hydrothermal overgrowth on zircons from a quartz vein is interpreted to represent the age of mineralisation.

\section{Acknowledgements}

Our thanks go to Kim Hein for improvements to the manuscript. We wish to gratefully acknowledge AMIRA International and the industry sponsors, as well as AusAID and the ARC Linkage Project LP110100667, for their support of the WAXI project (P934A). We are also appreciative of the contribution of the various Geological Surveys/Department of Mines in West Africa as sponsors in kind of WAXI. We wish to recognize our WAXI research colleagues from the various Institutions from around the world. We would like to thank SIGM for their permission to republish PRISM geological maps and magnetic data. We acknowledge the use of gravity data supplied by the BGI. Finally our thanks go to Kinross Gold Corporation for their permission to publish this paper. 
Black, L.P., Kamo, S.L., Allen, C.M., Aleinikoff, J.N., Davis, D.W., Korsch, R.J., Foudoulis, C. 2003. TEMORA 1: a new zircon standard for Phanerozoic U-Pb geochronology. Chemical Geology 200, 155-170.

Blake, C. 2011a. Mineralogical characterisation of five gold-bearing samples from the Tasiast mine, Mauritania for Kinross Gold Corporation. Internal unpublished report (February, 2011).

Blake, C. 2011b. Mineralogical characterisation of seven gold-bearing composite samples from the Tasiast Mine, Mauritania for Kinross Gold Corporation. Internal unpublished report (September, 2011).

Chardon, D. 1997. Les deformations continentals Archéennes. Examples naturels et modèlisation thermomécanique. Mémoires de Géosciences, Rennes, 76.

Chorlton, L.B. 2007. Generalized geology of the world: bedrock domains and major faults in GIS 416 format: a small-scale world geology map with an extended geological attribute database. 417 Geological Survey of Canada, Open File 5529, 2007; 48 pages; 1 CD-ROM, 418 doi:10.4095/223767.

Crowley, Q.G., Heron, K., Riggs, N., Kamber, B. Chew, D., McConnell, B., Benn, K. 2014. Chemical Abrasion Applied to LA-ICP-MS U-Pb Zircon Geochronology. Minerals 4, 503-518.

Ennih, N., Liegeois, J.-P. (eds) 2008. The Boundaries of the West African Craton. Geological Society, London, Special Publications, 297.

Gärtner, A., Villeneuve, M., Linnemann, U., Archi, A.E., Hervé, B. 2013. An exotic terrane of Laurussian affinity in the Mauritanides and Souttoufides (Moroccan Sahara). Gondwana Research 24, 687-699.

Jessell, M.W., Begg, G.C., Miller, M.S. 2015. The Geophysical Signatures of the West African Craton. in press, Precambrian Research, doi: 10.1016/j.precamres.2015.08.010.

JICA/OMRG Report on the Tasiast Gold Deposit. 2005. http://www.omrg.mr/spip.php?article88

Key, R.M., Loughlin, S.C., Horstwood, M.S.A., Gillespie, M., Pitfield, P.E.J., Henney, P.J., Crowley, Q.G., Del Rio, M. 2008. Two Mesoarchaean terranes in the Reguibat shield of NW Mauritania. In: Ennih, N., Liégeois, J.-P. (Eds.), Boundaries of the West African Craton, vol. 297. Special Publication of the Geological Society, London, pp. 33-52.

Krogh, T.E. 1982. Improved accuracy of U-Pb zircon ages by the creation of more concordant systems using an air abrasion technique. Geochimica et Cosmochimica Acta. Vol 46, pp 637-649.

Kruse, S., 2013. Regional geometry and tectonic evolution of the Aouéouat greenstone belt and Tasiast metallogenic district. Unpublished Internal Report for Kinross Tasiast, Terrane Geoscience Inc.

Ludwig, K.R. 2003. Isoplot 3.00: A geochronological toolkit for Microsoft Excel. Berkeley. Geochronology Centre Special Publication 4, 0-71. 
Marutani, M., Higashihara, M., Watanabe, Y., Murakami, H., Kojima G., Dioumassi, B. 2005. Metallic ore deposits in the Islamic Republic of Mauritania. Resource Geology, 55, 59-70.

Meyer, F.M., Kolb, J., Sakellaris, G.A., Gerdes, A. 2006. New ages from the Mauritanides Belt: recognition of Archean IOCG mineralization at Guelb Moghrein, Mauritania, Terra Nova, 18, 345-352.

Mining Journal. 2006. Mauritania: London, Mining Journal Special Publication, February 2006, 12 p. Montero, P., Haissen, F., Archi, A.E., Rjimati, E., Bea, F. 2014. Timing of Archean crust formation and cratonisation in the Awsard-Tichla zone of the NW Reguibat Rise, West African Craton. A SHRIMP, Nd-Sr isotopes, and geochemical reconnaissance study, Precambrian Research, 242, 112-137.

Paton, C., Hellstrom, J., Paul, B., Woodhead, J., Hergt, J. 2011. Iolite: Freeware for the visualisation and processing of mass spectrometric data. Journal of Analytical Atomic Spectrometry. 26, 25082518.

Petrus, J.A., Kamber, B.S. 2012. Vizualage: A novel approach to laser ablation ICP-MS U-Pb geochronology data reduction. Geostandards and Geoanalytical Research. 36, 247-270.

Rooney, A.D., Selby, D., Houzay, J.-P., Renne, P.R. 2010. Re-Os geochronology of a Mesoproterozoic sedimentary succession, Taoudeni basin, Mauritania: Implications for basin wide correlations and Re-Os organic-rich sediments systematic. Earth and Planetary Science Letters, v. 289, no. 3-4, pp. 486-496.

Schofield, D.I., Horstwood, M.S.A., Pitfield, P.E.J., Gillespie, M., Darbyshire, F., O’Connor, E.A., Abdouloye, T.B. 2012. U-Pb dating and Sm-Nd isotopic analysis of granitic rocks from the Tiris Complex: New constaints on key events in the evolution of the Reguibat Shield, Mauritania. Precambrian Research, 204-205, 1-11. doi:10.1016/j.precamres.2011.12.008.

Sims, J. 2014. Tasiast Project Mauritania National Instrument 43-101 Technical Report, prepared for Kinross Gold Corporation. 253p.

Sláma, J., Košler, J., Condon, D.J., Crowley, J.L., Gerdes, A., Hanchar, J.M., Horstwood, M.S., Morris, G.A., Nasdala, L., Norberg, N. 2008. Plešovice zircon-a new natural reference material for U$\mathrm{Pb}$ and Hf isotopic microanalysis. Chemical Geology. 249, 1-35.

Stuart, H. 2010. Technical Report on the Tasiast Gold Mine Islamic Republic of Mauritania for Red Back Mining Inc.: unpublished technical report prepared for Red Back Mining Inc., effective date 6 September 2010. 104p.

Taib, M. 2012. The Mineral Industry of Mauritania, USGS Minerals Yearbook 2012 (Advance Release). 6p.

Teal, D.J., Kah, L.C., 2005. Using C-isotopes to constrain interbasinal stratigraphic correlations, Mesoproterozoic Atar Group, Mauritania. Geological Society of America, Abstracts with Programs 37, 45. 
390

391

392

393

394

395

396

397

398

399

Villeneuve, M. 2008. Review of the orogenic belts on the western side of the West African craton: the Bassarides, Rokelides and Mauritanides. In: Ennih, N., Liégeois, J.-P. (Eds.), Boundaries of the West African Craton, vol. 297. Special Publication of the Geological Society, London, pp. 169201.

Wiedenbeck, M., Alle, P., Corfu, F., Griffin, W., Meier, M., Oberli, F., Quadt, A.v., Roddick, J., Spiegel, W. 1995. Three natural zircon standards for U-Th-Pb, Lu-Hf, trace element and REE analyses. Geostandards newsletter. 19, 1-23. 
400 Table 1: Early exploration history of the Tasiast region (after Stuart, 2010)

\begin{tabular}{|l|l|l|l|}
\hline Period & Operator & Activity & Exploration Scale \\
\hline \hline $1962-1963$ & BRGM & $\begin{array}{l}\text { The pegmatite Mission (for Be and } \\
\text { Li) }\end{array}$ & Regional \\
\hline 1972 & BRGM & Nickel Sulphide Mission & Regional \\
\hline $1973-1975$ & SNIM & Iron Ore Mission & Regional \\
\hline $1993-1996$ & BRGM + OMRG & $\begin{array}{l}\text { European Development Fund } \\
\text { project }\end{array}$ & Regional and infill \\
\hline
\end{tabular}

BRGM - Bureau de Recherches Géologique et Minières (French Geological Survey)

SNIM - Société Nationale Industrielle et Minière (Majority Mauritanian State-owned mining company)

OMRG - Office Mauritanien de Recherches Géologiques (Mauritanian Geological Survey)

Table 2 Mineral Reserve and Resource Summary

As at December 31, 2014

\section{Gold}

Proven and Probable Reserves

Measured and Indicated Resources (a)

Inferred Resources

Total (b)

$\begin{array}{ccc}\begin{array}{c}\text { Tonnes } \\ (\mathbf{X ~ 1 , 0 0 0 )}\end{array} & \begin{array}{c}\text { Grade } \\ (\mathbf{g} / \mathbf{t})\end{array} & \begin{array}{c}\text { Ounces } \\ (\mathbf{X ~ 1 , 0 0 0 )})\end{array} \\ 161,822 & 1.77 & 9,196 \\ 85,573 & 1.14 & 3,148 \\ 8,915 & 1.71 & 492 \\ \mathbf{2 5 6 , 3 1 0} & \mathbf{1 . 5 6} & \mathbf{1 2 , 8 3 6}\end{array}$

a) Measured and Indicated Resources exclude Proven and Probable Reserves

b) 'Total' Grade is the weighted average of the three cited grades according to Tonnes

After www.kinross.com/ operations/operation-tasiast-mauritania.aspx

Table 3 Production Summary

\begin{tabular}{cccccc} 
Year & $\begin{array}{c}\text { Tonnes Milled } \\
(\mathbf{M t})\end{array}$ & $\begin{array}{c}\text { Grade } \\
(\mathbf{g} / \mathbf{t})\end{array}$ & $\begin{array}{c}\text { Gold Produced } \\
\text { ('000 oz.) }\end{array}$ & $\begin{array}{c}\text { Dump Leach } \\
\text { Gold Produced } \\
\text { ('000 oz.) }\end{array}$ & $\begin{array}{c}\text { Total Gold Produced } \\
\text { ('000 oz.) }\end{array}$ \\
\hline 2013 & 2.50 & 1.96 & 144 & 104 & 248 \\
2012 & 2.55 & 1.54 & 114 & 71 & 185 \\
2011 & 2.61 & 2.53 & 153 & 48 & 201 \\
2010 & 2.14 & 2.46 & 151 & 36 & 187 \\
2009 & 1.69 & 2.87 & 143 & 16 & 159 \\
2008 & 1.49 & 3.10 & 140 & 0 & 140 \\
2007 & 0.22 & 4.77 & 21 & 0 & 21 \\
\hline
\end{tabular}

$401 \quad$ Table 3 from Sims, 2014.

402

403 
Figure 1. a) Geological Framework of the West African Craton, showing the location of the Tasiast deposit (gold) in Mauritania, together with the ages of the major terranes, modified from the Geological Survey of Canada 1:35M map of the world (Chorlton, 2007). The approximate limit of the present day WAC is shown as a heavy dashed line (after Ennih and Liegeois, 2008), and the limit of the gravity data shown in Figure 1b is shown as a dotted rectangle. Two-letter country codes: BF: Burkina Faso; CI: Côte d'Ivoire; DZ: Algeria; GH: Ghana; GM: The Gambia; GN: Guinea; GW: Guinea Bissau; LR: Liberia; MA: Morocco; ML: Mali; MR: Mauritania; NE: Niger; SL: Sierra Leone; SN: Senegal; and TO: Togo. b) Free Air gravity image of Northern Mauritania showing location of principal deposits.

Figure 2. a) Geological setting of the Tasiast deposit, (After PRISM 1:500k geological map). b) First Vertical Derivative of the Reduced to the Pole airborne magnetic data. The principal anomalies seen are the NNW traces of the BIFs, together with two sets of dykes, one solitary dyke trending NW just north of the Tasiast deposit, and a dense swarm of dykes trending $\mathrm{N}$ to NE that obscure much of the geological signal.

Figure 3. Location of principal deposits and their host rocks, as well as the main structural features 421 (After Stuart 2010).

Figure 4. a) Isoclinally folded sediments that are representative of the host rocks for all the Piment deposits, Tasiast Mine, pen for scale.. b) Strongly foliated meta-diorite from West Branch typical of the Greenschist Zone. c) Silica flooding and extensive sulphide mineralisation, mainly pyrrhotite, parallel to bedding in the metaturbidites at Piment. d) Visible gold hosted in a quartz-carbonate vein, in drill core taken from the West Branch deposit. e) Field location of quartz-carbonate vein TSUPB026. All core is $63.5 \mathrm{~mm}$ in diameter.

Figure 5. Samples used for zircon analysis. a) TSUPB015 is a sample of drill core from a hole located $7 \mathrm{~km}$ north of the Piment Central deposit in target C6.7 showing pervasive quartz-carbonate veining. b) TSUPB016 is a sample of drill core from a hole located $4 \mathrm{~km}$ east of the Piment deposits in target C6.12, showing pervasive quartz-carbonate veining. c) TSUPB026 was collected as a field sample of a quartzcarbonate vein from an exploration trench in the Fennec target, $10 \mathrm{~km}$ north of the Piment deposits. All core is $63.5 \mathrm{~mm}$ in diameter.

Figure 6. Representative CL-images of zircons used for U-Pb dating. a) TSUPB015 CL-images show oscillatory zoning in most grains indicating they are igneous in nature, with some showing metamict cores. Some of these xenocrystic zircons show a thin $(<10 \mu \mathrm{m})$ overgrowth seen by the dark CL rim surrounding the zircon on all sides, interpreted as hydrothermal in origin. b) TSUPB016 CL-images show oscillatory zoning with some metamict cores indicating they are xenocrystic, however none show 
442 evidence of hydrothermal overgrowths. c) TSUPB026 sample CL-images show igneous zircon with 443 oscillatory zoning, some with more complex zoning, and a number possessing cores. All zircons from 444 this sample had an obvious, generally $<10 \mu$ thick, overgrowth which is interpreted as hydrothermal in 445 origin.

446

447 Figure 7. U-Pb Concordia plots a) TSUPB015 analyses $<10 \%$ discordant. b) TSUPB016 upper448 intercept plot of concordant population. c) TSUPB016 analyses $<10 \%$ discordant. d) TSUPB026. e) 449 TSUPB026 upper intercept plot of analyses $<10 \%$ discordant. f) TSUPB026 upper-intercept plot of 450 hydrothermal overgrowth.

451

452 Table 1: Early exploration history of the Tasiast region (after Stuart, 2010).

453 Table 2 Mineral Reserve and Resource Summary (From Kinross Annual Report 2014).

454 Table 3 Production Summary (From Sims, 2014)

455

456 Supplementary Material

457 SM Table $1 \mathrm{U}-\mathrm{Pb}$ zircon data.

458

459 

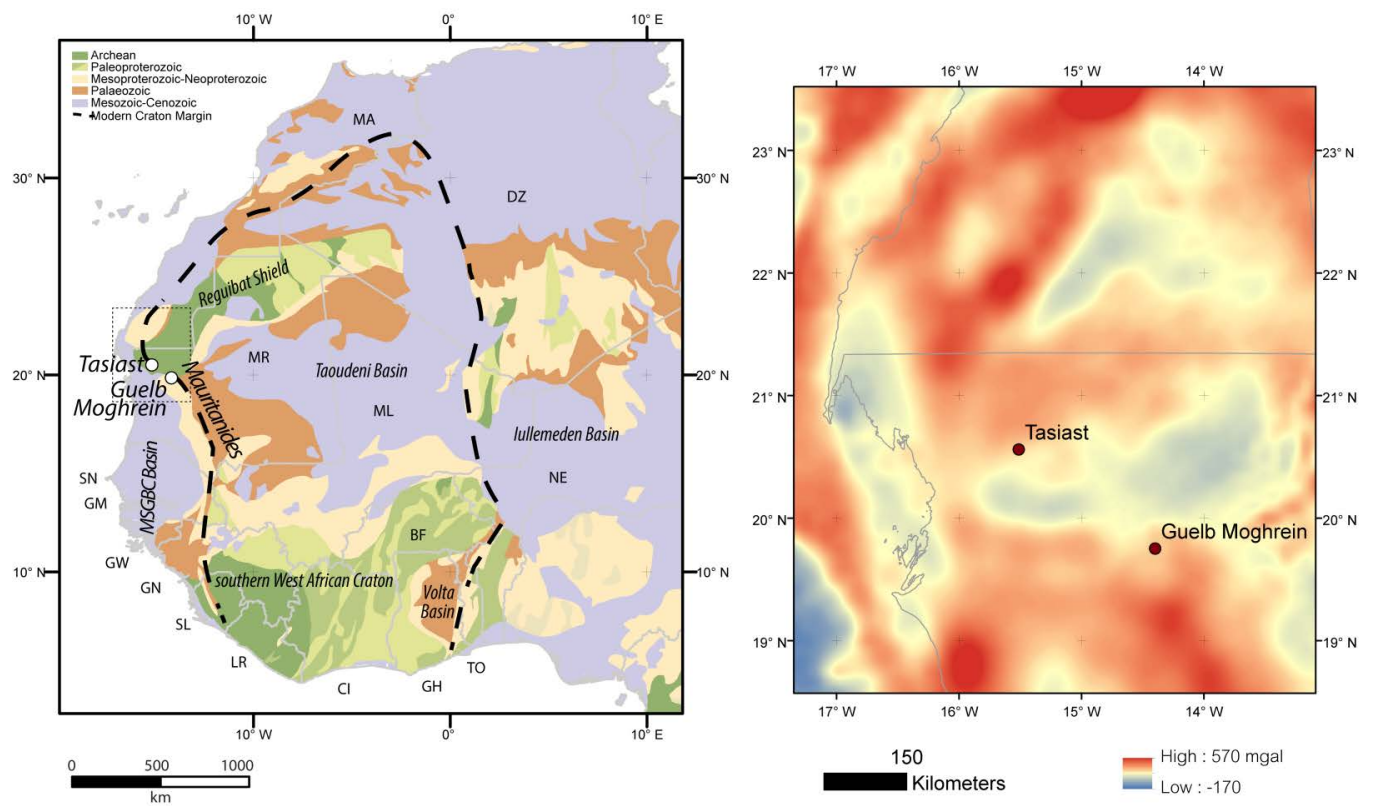

Figure 1a

Figure 1b 


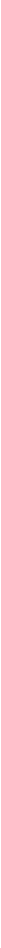




\section{a}

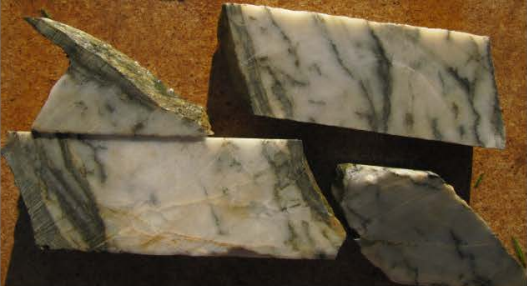

b

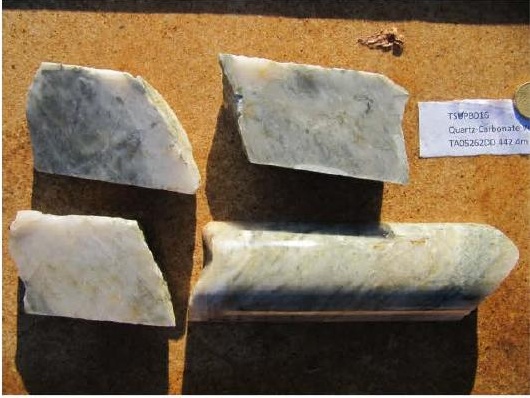

C

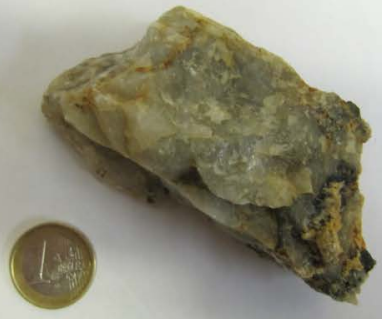

Figure 5 

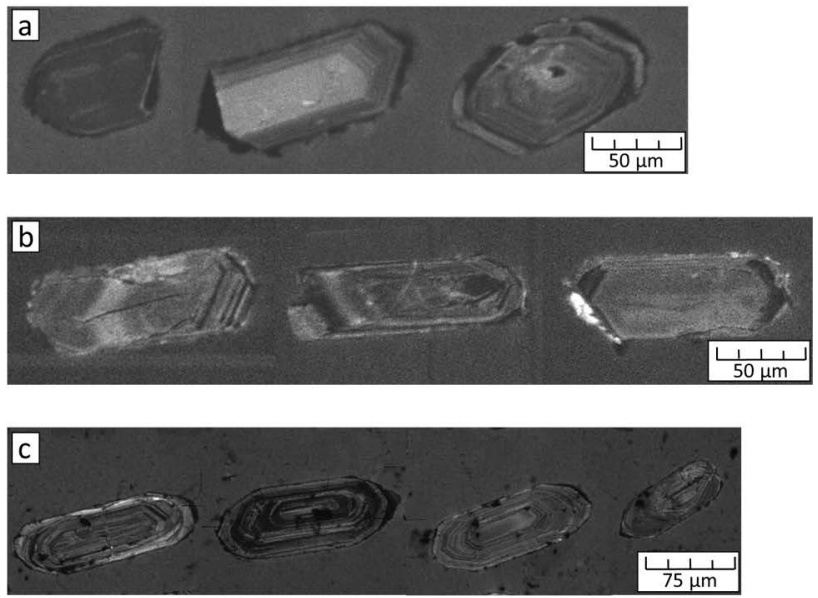

Figure 6 

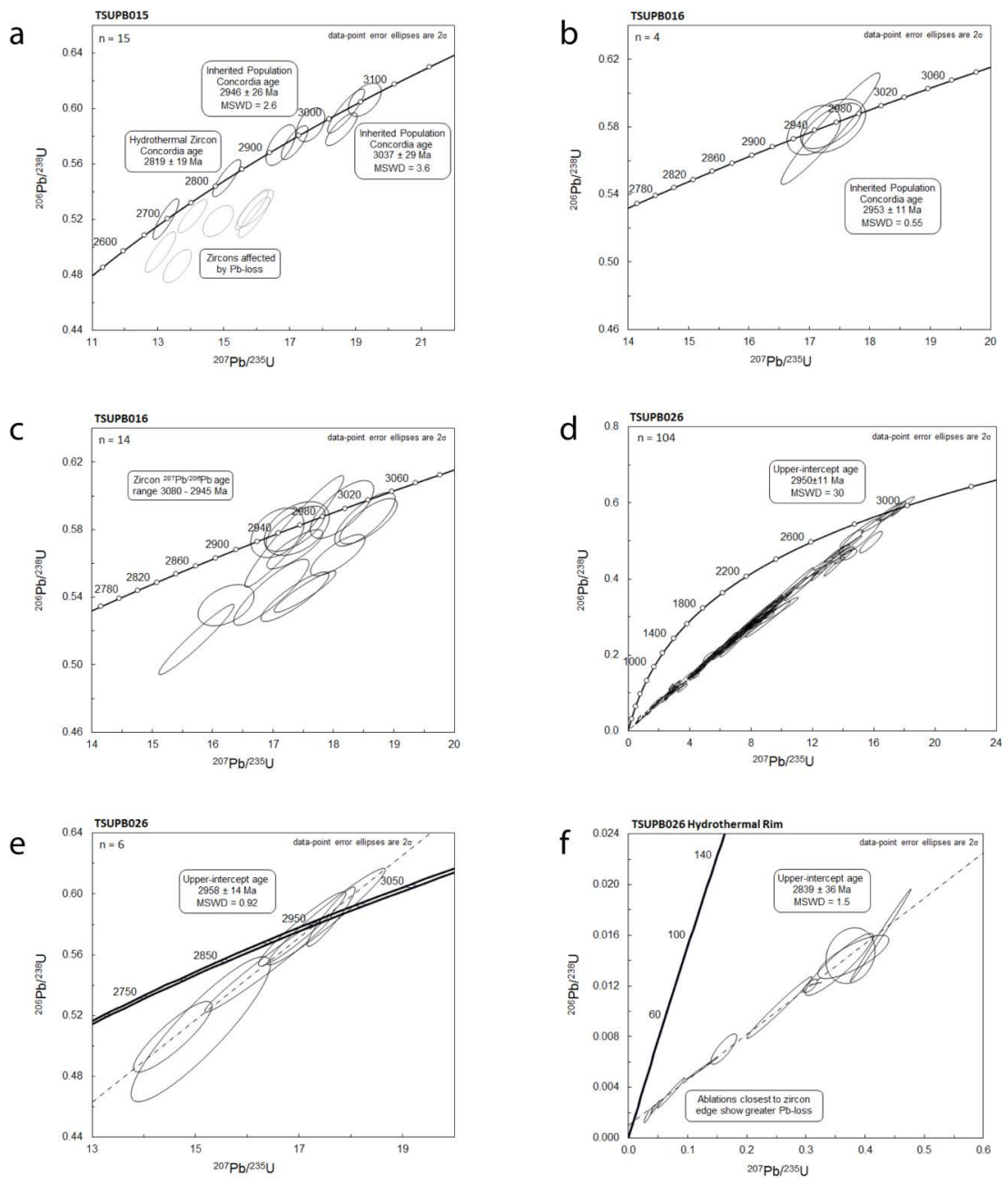

Figure 7 


\begin{tabular}{|c|c|c|c|c|c|c|c|c|c|c|c|c|c|c|c|c|}
\hline & \begin{tabular}{|c} 
Concentratio \\
$\mathrm{n}(\mathrm{ppm})$
\end{tabular} & & & & & atios & & & & & & $\mathrm{Ag}$ & e (Ma) & & & \\
\hline \begin{tabular}{|l} 
Sample \\
\end{tabular} & $\mathrm{U}$ & $\mathrm{Th} / \mathrm{U}$ & ${ }^{207} \mathrm{~Pb} /{ }^{235} \mathrm{U}$ & Err 2SE abs & ${ }^{206} \mathrm{~Pb} /{ }^{238} \mathrm{U}$ & Err 2SE abs & Rho & ${ }^{07} \mathrm{~Pb} /{ }^{206} \mathrm{~Pb}$ & Err 2SE abs & ${ }^{207} \mathrm{~Pb} /{ }^{235} \mathrm{U}$ & JErr 2SE abs & ${ }^{206} \mathrm{~Pb} /{ }^{238} \mathrm{U}$ & Err 2SE abs & ${ }^{207} \mathrm{~Pb} /{ }^{206} \mathrm{~Pb}$ & Err 2SE abs & $\%$ Discordant \\
\hline \begin{tabular}{|l} 
TSUPB015_1 \\
\end{tabular} & 634 & 0.97 & 9.100 & 0.320 & 0.3699 & 0.0110 & $\mid 0.92$ & 0.1710 & 0.0100 & 2346.0 & 33.0 & 2028.0 & 53.0 & 2568.0 & 10.0 & 18.1 \\
\hline \begin{tabular}{|l|} 
TSUPB015_2 \\
\end{tabular} & 191 & 0.73 & 13.240 & 0.320 & 0.5203 & 0.0120 & 0.86 & 0.1747 & 0.0100 & 2696.0 & 23.0 & 2699.0 & 50.0 & 2600.1 & 9.1 & 3.3 \\
\hline \begin{tabular}{|l|} 
TSUPB015_3 \\
\end{tabular} & 357 & 0.89 & 9.080 & 0.290 & 0.3514 & 0.0096 & 0.88 & 0.1759 & 0.0100 & 2345.0 & 29.0 & 1941.0 & 46.0 & 2621.0 & 8.0 & 24.7 \\
\hline TSUPB015_4 & 444 & 0.68 & 14.050 & 0.360 & 0.5224 & 0.0099 & 0.84 & 0.1876 & 0.0110 & 2753.0 & 25.0 & 2709.0 & 42.0 & 2720.8 & 9.9 & 2.6 \\
\hline TSUPB015_5 & 369 & 0.49 & 13.080 & 0.380 & 0.4964 & 0.0120 & 0.85 & 0.1887 & 0.0110 & 2684.0 & 28.0 & 2597.0 & 52.0 & 2729.0 & 10.0 & 4.9 \\
\hline TSUPB015_6 & 354 & 1.09 & 15.090 & 0.350 & 0.5498 & 0.0110 & 0.85 & 0.1895 & 0.0100 & 2821.0 & 22.0 & 2824.0 & 46.0 & 2743.2 & 6.2 & 1.4 \\
\hline TSUPB015_7 & 679 & 0.49 & 12.180 & 0.330 & 0.4449 & 0.0110 & 0.87 & 0.1910 & 0.0100 & 2620.0 & 24.0 & 2372.0 & 48.0 & 2753.3 & 8.4 & 13.8 \\
\hline TSUPB015_8 & 585 & 0.65 & 13.590 & 0.350 & 0.4862 & 0.0098 & 0.68 & 0.1940 & 0.0110 & 2721.0 & 24.0 & 2554.0 & 42.0 & 2791.9 & 8.8 & 9.1 \\
\hline \begin{tabular}{|l|} 
TSUPB015_9 \\
\end{tabular} & 162 & 2.67 & 3.255 & 0.360 & 0.1189 & 0.0095 & 0.62 & 0.2013 & 0.0140 & 1469.0 & 84.0 & 724.0 & 54.0 & 2825.0 & 23.0 & 66.9 \\
\hline \begin{tabular}{|l|} 
TSUPB015_10 \\
\end{tabular} & 531 & 1.01 & 11.010 & 0.320 & 0.3940 & 0.0089 & 0.59 & 0.2012 & 0.0100 & 2524.0 & 27.0 & 2141.0 & 41.0 & 2837.2 & 6.0 & 23.0 \\
\hline \begin{tabular}{|l|} 
TSUPB015_11 \\
\end{tabular} & 281 & 0.72 & 14.830 & 0.380 & 0.5188 & 0.0092 & 0.54 & 0.2066 & 0.0120 & 2804.0 & 24.0 & 2694.0 & 39.0 & 2869.0 & 19.0 & 6.3 \\
\hline TSUPB015_12 & 547 & 0.87 & 13.600 & 0.400 & 0.4724 & 0.0110 & 0.94 & 0.2060 & 0.0130 & 2720.0 & 28.0 & 2493.0 & 50.0 & 2878.0 & 12.0 & 12.8 \\
\hline TSUPB015_13 & 220 & 0.66 & 12.640 & 0.350 & 0.4424 & 0.0099 & 0.73 & 0.2074 & 0.0120 & 2652.0 & 26.0 & 2361.0 & 44.0 & 2885.0 & 11.0 & 16.5 \\
\hline \begin{tabular}{|l|} 
TSUPB015_14 \\
\end{tabular} & 182 & 0.48 & 12.680 & 0.540 & 0.4330 & 0.0140 & 0.87 & 0.2066 & 0.0120 & 2652.0 & 39.0 & 2317.0 & 65.0 & 2889.0 & 30.0 & 20.3 \\
\hline \begin{tabular}{|l} 
TSUPB015_15 \\
\end{tabular} & 384 & 0.99 & 17.150 & 0.330 & 0.5755 & 0.0100 & 0.76 & 0.2105 & 0.0130 & 2943.1 & 18.0 & 2930.0 & 43.0 & 2908.2 & 9.2 & 2.1 \\
\hline \begin{tabular}{|l|} 
TSUPB015_16 \\
\end{tabular} & 661 & 0.80 & 12.920 & 0.510 & 0.4310 & 0.0140 & 0.95 & 0.2116 & 0.0110 & 2675.0 & 35.0 & 2308.0 & 62.0 & 2916.0 & 18.0 & 21.3 \\
\hline TSUPB015_17 & 417 & 0.55 & 16.730 & 0.370 & 0.5737 & 0.0120 & 0.62 & 0.2118 & 0.0130 & 2920.0 & 22.0 & 2923.0 & 48.0 & 2920.0 & 17.0 & 2.3 \\
\hline \begin{tabular}{|l|} 
TSUPB015_18 \\
\end{tabular} & 736 & 0.90 & 13.830 & 0.350 & 0.4739 & 0.0110 & 0.87 & 0.2121 & 0.0110 & 2737.0 & 25.0 & 2500.0 & 49.0 & 2920.0 & 12.0 & 13.5 \\
\hline TSUPB015_19 & 659 & 1.04 & 12.220 & 0.420 & 0.4230 & 0.0140 & 0.95 & 0.2118 & 0.0120 & 2618.0 & 33.0 & 2272.0 & 64.0 & 2923.9 & 7.0 & 20.4 \\
\hline \begin{tabular}{|l|} 
TSUPB015_20 \\
\end{tabular} & 484 & 1.10 & 11.470 & 0.340 & 0.3663 & 0.0120 & 0.74 & 0.2148 & 0.0110 & 2561.0 & 28.0 & 2011.0 & 56.0 & 2938.0 & 23.0 & 34.2 \\
\hline \begin{tabular}{|l|} 
TSUPB015_21 \\
\end{tabular} & 301 & 0.57 & 17.640 & 0.350 & 0.5884 & 0.0100 & 0.44 & 0.2150 & 0.0130 & 2970.2 & 19.0 & 2983.0 & 41.0 & 2941.0 & 11.0 & 1.9 \\
\hline TSUPB015_22 & 662 & 0.99 & 15.850 & 0.410 & 0.5271 & 0.0120 & 0.90 & 0.2160 & 0.0130 & 2867.0 & 25.0 & 2729.0 & 50.0 & 2947.4 & 7.9 & 7.5 \\
\hline \begin{tabular}{|l|} 
TSUPB015_23 \\
\end{tabular} & 492 & 0.99 & 11.670 & 0.300 & 0.3881 & 0.0110 & 0.68 & 0.2159 & 0.0110 & 2578.5 & 24.0 & 2113.0 & 50.0 & 2948.3 & 9.4 & 28.5 \\
\hline \begin{tabular}{|l|} 
TSUPB015_24 \\
\end{tabular} & 815 & 1.06 & 10.990 & 0.720 & 0.3590 & 0.0150 & 0.94 & 0.2194 & 0.0130 & 2525.0 & 61.0 & 1977.0 & 71.0 & 2968.0 & 31.0 & 35.2 \\
\hline \begin{tabular}{|l} 
TSUPB015_25 \\
\end{tabular} & 546 & 0.39 & 15.920 & 0.390 & 0.5216 & 0.0120 & 0.88 & 0.2206 & 0.0120 & 2872.0 & 24.0 & 2706.0 & 51.0 & 2980.9 & 8.1 & 9.6 \\
\hline \begin{tabular}{|l} 
TSUPB015_26 \\
\end{tabular} & 822 & 0.53 & 13.050 & 0.550 & 0.4400 & 0.0200 & 0.97 & 0.2207 & 0.0120 & 2681.0 & 40.0 & 2349.0 & 88.0 & 2992.0 & 18.0 & 19.6 \\
\hline TSUPB015_27 & 497 & 0.81 & 15.960 & 0.450 & 0.5279 & 0.0110 & 0.81 & 0.2217 & 0.0130 & 2873.0 & 26.0 & 2732.0 & 47.0 & 2994.0 & 16.0 & 8.4 \\
\hline \begin{tabular}{|l} 
TSUPB015_28 \\
\end{tabular} & 326 & 0.62 & 18.710 & 0.460 & 0.5983 & 0.0130 & 0.88 & 0.2289 & 0.0140 & 3026.0 & 24.0 & 3022.0 & 51.0 & 3047.4 & 8.5 & 3.7 \\
\hline \begin{tabular}{|l|} 
TSUPB015_29 \\
\end{tabular} & 405 & 0.56 & 18.570 & 0.390 & 0.5852 & 0.0097 & 0.80 & 0.2310 & 0.0130 & 3019.5 & 20.0 & 2970.0 & 39.0 & 3059.1 & 8.3 & 2.9 \\
\hline \begin{tabular}{|l|} 
TSUPB015_30 \\
\end{tabular} & 357 & 0.58 & 19.280 & 0.410 & 0.6065 & 0.0099 & 0.51 & 0.2311 & 0.0140 & 3057.3 & 20.0 & 3056.0 & 40.0 & 3060.2 & 5.3 & 1.6 \\
\hline TSUPB015_31 & 358 & 0.53 & 14.250 & 0.410 & 0.4458 & 0.0098 & 0.59 & 0.2310 & 0.0140 & 2767.0 & 27.0 & 2376.0 & 44.0 & 3061.0 & 12.0 & 22.9 \\
\hline \begin{tabular}{|l|} 
TSUPB015_32 \\
\end{tabular} & 776 & 1.32 & 11.400 & 0.500 & 0.3591 & 0.0120 & 0.92 & 0.2321 & 0.0120 & 2551.0 & 39.0 & 1977.0 & 56.0 & 3066.0 & 16.0 & 36.0 \\
\hline TSUPB015_33 & 360 & 1.17 & 17.340 & 0.410 & 0.5365 & 0.0098 & 0.64 & 0.2331 & 0.0140 & 2953.5 & 23.0 & 2768.0 & 41.0 & 3072.2 & 6.8 & 10.3 \\
\hline \begin{tabular}{|l|} 
TSUPB015_34 \\
\end{tabular} & 533 & 0.46 & 16.640 & 0.580 & 0.5110 & 0.0140 & 0.93 & 0.2354 & 0.0140 & 2913.0 & 33.0 & 2661.0 & 62.0 & 3090.0 & 39.0 & 13.8 \\
\hline \begin{tabular}{|l} 
TSUPB015_35 \\
\end{tabular} & 577 & 0.78 & 17.400 & 0.430 & 0.5377 & 0.0110 & 0.73 & 0.2374 & 0.0140 & 2956.0 & 24.0 & 2774.0 & 48.0 & 3101.0 & 15.0 & 10.1 \\
\hline TSUPB015_36 & 294 & 0.96 & 16.160 & 0.470 & 0.4954 & 0.0110 & 0.92 & 0.2395 & 0.0140 & 2885.0 & 28.0 & 2594.0 & 46.0 & 3114.0 & 15.0 & 16.7 \\
\hline TSUPB015_37 & 1890 & 0.85 & 6.380 & 0.420 & 0.1926 & 0.0110 & 0.87 & 0.2416 & 0.0140 & 2024.0 & 56.0 & 1135.0 & 57.0 & 3136.0 & 27.0 & 69.9 \\
\hline \begin{tabular}{|l|} 
TSUPB015_38 \\
\end{tabular} & 729 & 0.39 & 14.590 & 0.450 & 0.4354 & 0.0110 & 0.80 & 0.2475 & 0.0140 & 2788.0 & 29.0 & 2330.0 & 51.0 & 3164.0 & 13.0 & 28.1 \\
\hline
\end{tabular}




\begin{tabular}{|c|c|c|c|c|c|c|c|c|c|c|c|c|c|c|c|c|}
\hline TSUPB015_39 & 817 & 0.44 & 13.470 & 0.560 & 0.3890 & 0.0140 & 0.90 & 0.2555 & 0.0140 & 2710.0 & 39.0 & 2125.0 & 61.0 & 3222.0 & 17.0 & 37.7 \\
\hline TSUPB015_40 & 2374 & 1.61 & 12.240 & 0.580 & 0.3530 & 0.0140 & 0.99 & 0.2571 & 0.0120 & 2622.0 & 44.0 & 1948.0 & 69.0 & 3227.0 & 46.0 & 42.3 \\
\hline TSUPB015_41 & 1378 & 1.02 & 10.910 & 0.390 & 0.3164 & 0.0120 & 0.87 & 0.2585 & 0.0120 & 2514.0 & 34.0 & 1771.0 & 59.0 & 3238.0 & 15.0 & 50.2 \\
\hline TSUPB015_42 & 313 & 0.91 & 11.420 & 0.480 & 0.3188 & 0.0110 & 0.94 & 0.2595 & 0.0130 & 2562.0 & 40.0 & 1788.0 & 53.0 & 3247.0 & 10.0 & 52.8 \\
\hline \begin{tabular}{|l|} 
TSUPB015_43 \\
\end{tabular} & 910 & 1.12 & 13.000 & 0.510 & 0.3498 & 0.0120 & 0.97 & 0.2663 & 0.0140 & 2678.0 & 38.0 & 1933.0 & 59.0 & 3279.0 & 17.0 & 49.3 \\
\hline & & & & & & & & & & & & & & & & \\
\hline TSUPB016_1 & 801 & 0.29 & 5.110 & 0.590 & 0.1680 & 0.0150 & 1.00 & 0.2097 & 0.0130 & 1833.0 & 96.0 & 997.0 & 83.0 & 2904.0 & 30.0 & 65.7 \\
\hline TSUPB016_2 & 3800 & 0.09 & 1.720 & 0.360 & 0.0557 & 0.0089 & 0.93 & 0.2140 & 0.0150 & 1006.0 & 140.0 & 349.0 & 54.0 & 2925.0 & 50.0 & 77.3 \\
\hline \begin{tabular}{|l|} 
TSUPB016_3 \\
\end{tabular} & 366 & 0.27 & 15.240 & 0.410 & 0.4993 & 0.0110 & 0.86 & 0.2122 & 0.0130 & 2830.0 & 25.0 & 2611.0 & 48.0 & 2928.0 & 10.0 & 11.9 \\
\hline \begin{tabular}{|l|} 
TSUPB016_4 \\
\end{tabular} & 1443 & 0.15 & 9.120 & 0.430 & 0.3054 & 0.0130 & 0.98 & 0.2138 & 0.0130 & 2346.0 & 43.0 & 1716.0 & 64.0 & 2934.0 & 6.1 & 42.2 \\
\hline TSUPB016_5 & 207 & 0.47 & 17.370 & 0.400 & 0.5806 & 0.0110 & 0.65 & 0.2160 & 0.0130 & 2955.0 & 22.0 & 2951.0 & 46.0 & 2942.5 & 6.1 & 2.0 \\
\hline TSUPB016_6 & 325 & 0.32 & 15.240 & 0.420 & 0.4999 & 0.0130 & 0.73 & 0.2163 & 0.0140 & 2830.0 & 26.0 & 2613.0 & 55.0 & 2949.0 & 6.0 & 12.8 \\
\hline TSUPB016_7 & 375 & 0.34 & 15.730 & 0.510 & 0.5150 & 0.0170 & 0.96 & 0.2167 & 0.0130 & 2859.0 & 31.0 & 2676.0 & 72.0 & 2955.2 & 4.4 & 9.6 \\
\hline TSUPB016_8 & 272 & 0.46 & 17.360 & 0.380 & 0.5684 & 0.0095 & 0.82 & 0.2166 & 0.0130 & 2954.6 & 21.0 & 2901.0 & 39.0 & 2958.8 & 6.7 & 2.8 \\
\hline \begin{tabular}{|l|} 
TSUPB016_9 \\
\end{tabular} & 458 & 0.29 & 17.350 & 0.670 & 0.5790 & 0.0270 & 0.96 & 0.2191 & 0.0130 & 2952.0 & 38.0 & 2940.0 & 110.0 & 2973.0 & 10.0 & 6.5 \\
\hline TSUPB016_10 & 168 & 0.45 & 17.390 & 0.440 & 0.5807 & 0.0130 & 0.43 & 0.2193 & 0.0130 & 2956.0 & 24.0 & 2951.0 & 53.0 & 2977.0 & 17.0 & 3.2 \\
\hline TSUPB016_11 & 208 & \begin{tabular}{|l|}
0.19 \\
\end{tabular} & 12.680 & 0.380 & 0.4168 & 0.0097 & 0.70 & 0.2191 & 0.0140 & 2656.0 & 28.0 & 2246.0 & 44.0 & 2980.0 & 13.0 & 24.6 \\
\hline \begin{tabular}{|l|} 
TSUPB016_12 \\
\end{tabular} & 295 & 0.36 & 10.380 & 0.540 & 0.3320 & 0.0140 & 0.86 & 0.2211 & 0.0130 & 2462.0 & 48.0 & 1847.0 & 66.0 & 2981.0 & 14.0 & 38.3 \\
\hline TSUPB016_13 & 384 & 0.46 & 13.700 & 0.410 & 0.4616 & 0.0100 & 0.69 & 0.2194 & 0.0130 & 2729.0 & 28.0 & 2446.0 & 45.0 & 2982.0 & 12.0 & 15.8 \\
\hline TSUPB016_14 & 521 & 0.50 & 11.020 & 0.470 & 0.3584 & 0.0120 & 0.91 & 0.2203 & 0.0130 & 2529.0 & 41.0 & 1973.0 & 58.0 & 2982.0 & 20.0 & 35.2 \\
\hline TSUPB016_15 & 359 & 0.33 & 17.070 & 0.360 & 0.5781 & 0.0120 & 0.37 & 0.2228 & 0.0130 & 2938.8 & 20.0 & 2941.0 & 47.0 & 2999.0 & 9.5 & 1.8 \\
\hline TSUPB016_16 & 178 & 0.28 & 18.580 & 0.390 & 0.5850 & 0.0110 & 0.76 & 0.2224 & 0.0130 & 3020.0 & 20.0 & 2969.0 & 44.0 & 3001.6 & 8.6 & 2.5 \\
\hline \begin{tabular}{|l|l} 
TSUPB016_17 \\
\end{tabular} & 218 & 0.30 & 18.520 & 0.410 & 0.5862 & 0.0130 & 0.77 & 0.2230 & 0.0140 & 3019.0 & 21.0 & 2973.0 & 53.0 & 3005.0 & 14.0 & 4.0 \\
\hline \begin{tabular}{|l|} 
TSUPB016_18 \\
\end{tabular} & 277 & 0.34 & 18.140 & 0.430 & 0.5920 & 0.0140 & 0.71 & 0.2247 & 0.0140 & 2997.0 & 23.0 & 2996.0 & 59.0 & 3020.0 & 14.0 & 3.2 \\
\hline \begin{tabular}{|l|} 
TSUPB016_19 \\
\end{tabular} & 161 & 0.25 & 18.070 & 0.370 & 0.5649 & 0.0100 & 0.78 & 0.2268 & 0.0140 & 2993.0 & 20.0 & 2886.0 & 42.0 & 3024.6 & 6.9 & 6.1 \\
\hline TSUPB016_20 & 404 & 0.33 & 16.220 & 0.380 & 0.5353 & 0.0100 & 0.44 & 0.2266 & 0.0130 & 2892.0 & 25.0 & 2764.0 & 42.0 & 3030.5 & 9.4 & 7.0 \\
\hline \begin{tabular}{|l|} 
TSUPB016_21 \\
\end{tabular} & 457 & 0.35 & 14.770 & 0.520 & 0.4740 & 0.0150 & 0.91 & 0.2294 & 0.0130 & 2804.0 & 32.0 & 2498.0 & 66.0 & 3045.6 & 7.3 & 17.3 \\
\hline TSUPB016_22 & 320 & 0.49 & 16.210 & 0.400 & 0.4943 & 0.0110 & 0.70 & 0.2295 & 0.0130 & 2889.0 & 24.0 & 2589.0 & 46.0 & 3050.2 & 7.8 & 17.0 \\
\hline TSUPB016_23 & 432 & 0.25 & 16.020 & 0.390 & 0.5183 & 0.0130 & 0.88 & 0.2297 & 0.0130 & 2878.0 & 23.0 & 2691.0 & 54.0 & 3055.0 & 15.0 & 10.9 \\
\hline TSUPB016_24 & 512 & 0.43 & 12.160 & 0.400 & 0.3823 & 0.0100 & 0.93 & 0.2311 & 0.0140 & 2615.0 & 31.0 & 2087.0 & 47.0 & 3055.0 & 17.0 & 33.2 \\
\hline TSUPB016_25 & 136 & \begin{tabular}{|l|}
0.17 \\
\end{tabular} & 17.360 & 0.460 & 0.5403 & 0.0120 & 0.88 & 0.2301 & 0.0140 & 2954.0 & 25.0 & 2784.0 & 48.0 & 3057.5 & 6.8 & 9.3 \\
\hline \begin{tabular}{|l|} 
TSUPB016_26 \\
\end{tabular} & 1370 & 0.34 & 4.698 & 0.350 & 0.1447 & 0.0096 & 0.80 & 0.2314 & 0.0140 & 1766.0 & 61.0 & 871.0 & 54.0 & 3059.0 & 28.0 & 74.4 \\
\hline TSUPB016_27 & 533 & 0.68 & 17.530 & 0.420 & 0.5433 & 0.0100 & 0.93 & 0.2317 & 0.0130 & 2963.0 & 23.0 & 2797.0 & 42.0 & 3061.6 & 5.9 & 9.3 \\
\hline \begin{tabular}{|l|} 
TSUPB016_28 \\
\end{tabular} & 89 & 0.21 & 14.840 & 0.380 & 0.4792 & 0.0097 & 0.27 & 0.2317 & 0.0140 & 2805.0 & 24.0 & 2524.0 & 42.0 & 3065.0 & 13.0 & 16.1 \\
\hline TSUPB016_29 & 1307 & 0.09 & 5.280 & 0.640 & 0.1500 & 0.0140 & 0.85 & 0.2340 & 0.0160 & 1835.0 & 110.0 & 899.0 & 78.0 & 3067.0 & 65.0 & 77.0 \\
\hline \begin{tabular}{|l|} 
TSUPB016_30 \\
\end{tabular} & 366 & 0.31 & 16.970 & 0.510 & 0.5430 & 0.0160 & 0.88 & 0.2355 & 0.0140 & 2932.0 & 29.0 & 2797.0 & 67.0 & 3083.0 & 20.0 & 8.0 \\
\hline \begin{tabular}{|l|} 
TSUPB016_31 \\
\end{tabular} & 951 & 0.25 & 4.433 & 0.340 & 0.1358 & 0.0088 & 0.37 & 0.2341 & 0.0140 & 1718.4 & 63.0 & 821.0 & 50.0 & 3083.0 & 21.0 & 77.8 \\
\hline \begin{tabular}{|l|l|} 
TSUPB016_32 \\
\end{tabular} & 474 & 0.11 & 3.960 & 0.350 & 0.1205 & 0.0091 & 0.97 & 0.2337 & 0.0140 & 1623.0 & 72.0 & 733.0 & 52.0 & 3083.0 & 13.0 & 79.8 \\
\hline TSUPB016_33 & 166 & 0.13 & 15.950 & 0.380 & 0.5017 & 0.0096 & 0.60 & 0.2361 & 0.0140 & 2873.0 & 23.0 & 2621.0 & 41.0 & 3092.7 & 8.6 & 14.1 \\
\hline TSUPB016_34 & 385 & 0.49 & 15.010 & 0.370 & 0.4450 & 0.0096 & 0.69 & 0.2359 & 0.0130 & 2816.0 & 24.0 & 2373.0 & 43.0 & 3093.0 & 12.0 & 26.8 \\
\hline \begin{tabular}{|l} 
TSUPB016_35 \\
\end{tabular} & 952 & 0.31 & 8.840 & 0.390 & 0.2673 & 0.0110 & 0.95 & 0.2386 & 0.0140 & 2319.0 & 41.0 & 1526.0 & 58.0 & 3094.0 & 24.0 & 56.9 \\
\hline
\end{tabular}




\begin{tabular}{|c|c|c|c|c|c|c|c|c|c|c|c|c|c|c|c|c|}
\hline \begin{tabular}{|l|} 
TSUPB016_36 \\
\end{tabular} & 234 & 0.20 & 14.960 & 0.410 & 0.4707 & 0.0110 & 0.88 & 0.2394 & 0.0140 & 2813.0 & 26.0 & 2487.0 & 50.0 & 3115.0 & 11.0 & 18.8 \\
\hline TSUPB016_37 & 243 & 0.24 & 12.510 & 0.390 & 0.3761 & 0.0110 & 0.90 & 0.2424 & 0.0140 & 2647.0 & 32.0 & 2057.0 & 50.0 & 3136.0 & 11.0 & 37.6 \\
\hline TSUPB016_38 & 311 & 0.33 & 19.480 & 0.440 & 0.5651 & 0.0110 & 0.65 & 0.2439 & 0.0130 & 3065.0 & 22.0 & 2887.0 & 45.0 & 3146.0 & 16.0 & 10.9 \\
\hline TSUPB016_39 & 952 & 0.36 & 6.498 & 0.340 & 0.1896 & 0.0089 & 0.87 & 0.2450 & 0.0130 & 2045.0 & 47.0 & 1119.0 & 48.0 & 3151.7 & 6.8 & 73.0 \\
\hline \begin{tabular}{|l|} 
TSUPB016_40 \\
\end{tabular} & 791 & 0.40 & 13.520 & 0.440 & 0.4070 & 0.0160 & 0.97 & 0.2451 & 0.0130 & 2716.0 & 31.0 & 2200.0 & 74.0 & 3156.0 & 12.0 & 31.9 \\
\hline \begin{tabular}{|l|} 
TSUPB016_41 \\
\end{tabular} & 618 & 0.44 & 11.070 & 0.390 & 0.3208 & 0.0089 & 0.63 & 0.2459 & 0.0140 & 2529.0 & 33.0 & 1794.0 & 44.0 & 3158.0 & 15.0 & 50.0 \\
\hline \begin{tabular}{|l} 
TSUPB016_42 \\
\end{tabular} & 636 & 0.34 & 13.330 & 0.490 & 0.4080 & 0.0140 & 0.72 & 0.2462 & 0.0150 & 2703.0 & 35.0 & 2204.0 & 66.0 & 3162.0 & 36.0 & 29.7 \\
\hline TSUPB016_43 & 538 & 0.20 & 8.650 & 0.550 & 0.2407 & 0.0093 & 0.57 & 0.2530 & 0.0170 & 2296.0 & 58.0 & 1390.0 & 48.0 & 3194.0 & 64.0 & 67.4 \\
\hline TSUPB016_44 & 220 & 0.12 & 14.100 & 0.440 & 0.3930 & 0.0150 & 0.89 & 0.2563 & 0.0140 & 2756.0 & 30.0 & 2138.0 & 70.0 & 3218.0 & 25.0 & 40.2 \\
\hline \begin{tabular}{|l} 
TSUPB016_45 \\
\end{tabular} & 619 & 0.72 & 13.770 & 0.520 & 0.3699 & 0.0110 & 0.70 & 0.2611 & 0.0140 & 2733.0 & 35.0 & 2029.0 & 53.0 & 3264.0 & 22.0 & 45.8 \\
\hline TSUPB016_46 & 282 & 0.18 & 19.360 & 0.420 & 0.5340 & 0.0150 & 0.29 & 0.2668 & 0.0150 & 3060.0 & 21.0 & 2755.0 & 65.0 & 3287.0 & 38.0 & 15.7 \\
\hline TSUPB016_47 & 1137 & 0.58 & 8.340 & 0.370 & 0.2249 & 0.0090 & 0.85 & 0.2706 & 0.0130 & 2267.0 & 40.0 & 1310.0 & 50.0 & 3307.0 & 16.0 & 73.6 \\
\hline \begin{tabular}{|l|} 
TSUPB016_48 \\
\end{tabular} & 813 & 0.26 & 12.230 & 0.460 & 0.3123 & 0.0120 & 0.97 & 0.2842 & 0.0140 & 2619.0 & 37.0 & 1751.0 & 60.0 & 3380.0 & 15.0 & 61.1 \\
\hline & & & & & & & & & & & & & & & & \\
\hline \begin{tabular}{|l|} 
TSUPB026_1 \\
\end{tabular} & 2950 & \begin{tabular}{|c|}
1.17 \\
\end{tabular} & 0.720 & 0.091 & 0.0355 & 0.0041 & $\mid 0.95$ & 0.1461 & 0.0025 & 548.0 & 55.0 & 225.0 & 26.0 & 2301.0 & 29.0 & 90.3 \\
\hline TSUPB026_2 & 4000 & 0.50 & 0.608 & 0.076 & 0.0260 & 0.0029 & \begin{tabular}{|l|}
0.93 \\
\end{tabular} & 0.1702 & 0.0055 & 478.0 & 48.0 & 165.0 & 18.0 & 2556.0 & 55.0 & 93.6 \\
\hline TSUPB026_3 & 1400 & 1.50 & 1.200 & 0.056 & 0.0491 & 0.0031 & 0.92 & 0.1724 & 0.0041 & 799.0 & 25.0 & 309.0 & 19.0 & 2578.0 & 39.0 & 88.1 \\
\hline \begin{tabular}{|l|} 
TSUPB026_4 \\
\end{tabular} & 1100 & 0.12 & 2.790 & 0.120 & 0.1163 & 0.0066 & 0.94 & 0.1720 & 0.0037 & 1360.0 & 36.0 & 709.0 & 38.0 & 2582.0 & 34.0 & 72.1 \\
\hline TSUPB026_5 & 5200 & 0.62 & 0.580 & 0.100 & 0.0229 & 0.0034 & 0.99 & 0.1735 & 0.0041 & 453.0 & 67.0 & 146.0 & 21.0 & 2590.0 & 39.0 & 94.4 \\
\hline TSUPB026_6 & 1120 & 0.28 & 2.020 & 0.140 & 0.0817 & 0.0065 & 0.94 & 0.1771 & 0.0035 & 1116.0 & 48.0 & 506.0 & 39.0 & 2625.0 & 33.0 & 81.2 \\
\hline TSUPB026_7 & 1020 & 0.21 & 1.720 & 0.240 & 0.0712 & 0.0093 & 0.97 & 0.1773 & 0.0050 & 999.0 & 94.0 & 442.0 & 56.0 & 2625.0 & 48.0 & 83.2 \\
\hline TSUPB026_8 & 1020 & 0.23 & 1.134 & 0.045 & 0.0464 & 0.0020 & 0.83 & 0.1773 & 0.0036 & 769.0 & 21.0 & 292.0 & 12.0 & 2626.0 & 33.0 & 88.8 \\
\hline TSUPB026_9 & 1110 & 0.14 & 0.962 & 0.028 & 0.0389 & 0.0010 & 0.50 & 0.1790 & 0.0045 & 684.0 & 15.0 & 246.2 & 5.9 & 2642.0 & 42.0 & 90.7 \\
\hline \begin{tabular}{|l|} 
TSUPB026_10 \\
\end{tabular} & 420 & 0.22 & 1.530 & 0.130 & 0.0615 & 0.0055 & 0.89 & 0.1823 & 0.0070 & 935.0 & 52.0 & 384.0 & 33.0 & 2668.0 & 64.0 & 85.5 \\
\hline \begin{tabular}{|l|} 
TSUPB026_11 \\
\end{tabular} & 1180 & 0.41 & 1.757 & 0.056 & 0.0699 & 0.0017 & 0.89 & 0.1829 & 0.0033 & 1029.0 & 20.0 & 436.0 & 10.0 & 2679.0 & 30.0 & 83.6 \\
\hline \begin{tabular}{|l} 
TSUPB026_12 \\
\end{tabular} & 3480 & 0.47 & 0.211 & 0.028 & 0.0083 & 0.0011 & 0.97 & 0.1836 & 0.0065 & 194.0 & 23.0 & 53.3 & 7.2 & 2682.0 & 57.0 & 98.0 \\
\hline \begin{tabular}{|l|} 
TSUPB026_13 \\
\end{tabular} & 2120 & 0.47 & 3.040 & 0.310 & 0.1200 & 0.0110 & 0.98 & 0.1836 & 0.0034 & 1402.0 & 91.0 & 731.0 & 64.0 & 2685.0 & 30.0 & 73.0 \\
\hline TSUPB026_14 & 3280 & 0.41 & 0.607 & 0.036 & 0.0245 & 0.0014 & 0.97 & 0.1847 & 0.0036 & 481.0 & 23.0 & 155.8 & 8.6 & 2695.0 & 33.0 & 94.2 \\
\hline TSUPB026_15 & 1230 & 0.30 & 2.450 & 0.200 & 0.0946 & 0.0066 & 0.98 & 0.1850 & 0.0033 & 1251.0 & 60.0 & 582.0 & 39.0 & 2697.0 & 29.0 & 78.5 \\
\hline TSUPB026_16 & 668 & 0.33 & 3.150 & 0.160 & 0.1221 & 0.0062 & 0.85 & 0.1853 & 0.0035 & 1452.0 & 36.0 & 742.0 & 36.0 & 2700.0 & 32.0 & 72.6 \\
\hline TSUPB026_17 & 2700 & 0.69 & 0.322 & 0.017 & 0.0126 & 0.0006 & 0.95 & 0.1873 & 0.0044 & 283.0 & 13.0 & 80.5 & 3.8 & 2717.0 & 39.0 & 97.0 \\
\hline \begin{tabular}{|l|} 
TSUPB026_18 \\
\end{tabular} & 1098 & 0.13 & 2.954 & 0.098 & 0.1145 & 0.0031 & 0.94 & 0.1871 & 0.0018 & 1393.0 & 25.0 & 699.0 & 18.0 & 2719.0 & 16.0 & 74.3 \\
\hline \begin{tabular}{|l|} 
TSUPB026_19 \\
\end{tabular} & 2040 & 0.55 & 0.311 & 0.023 & 0.0123 & 0.0007 & 0.78 & 0.1883 & 0.0049 & 274.0 & 18.0 & 78.7 & 4.3 & 2721.0 & 43.0 & 97.2 \\
\hline \begin{tabular}{|l|} 
TSUPB026_20 \\
\end{tabular} & 1220 & 0.34 & 2.170 & 0.084 & 0.0838 & 0.0039 & 0.90 & 0.1885 & 0.0030 & 1171.0 & 26.0 & 519.0 & 23.0 & 2729.0 & 27.0 & 81.0 \\
\hline \begin{tabular}{|l} 
TSUPB026_21 \\
\end{tabular} & 1440 & 0.49 & 2.010 & 0.140 & 0.0780 & 0.0050 & 0.95 & 0.1899 & 0.0047 & 1114.0 & 51.0 & 484.0 & 30.0 & 2739.0 & 41.0 & 82.2 \\
\hline \begin{tabular}{|l|} 
TSUPB026_22 \\
\end{tabular} & 810 & 0.28 & 2.580 & 0.170 & 0.0965 & 0.0079 & 0.85 & 0.1876 & 0.0063 & 1289.0 & 50.0 & 593.0 & 46.0 & 2750.0 & 58.0 & 78.3 \\
\hline \begin{tabular}{|l} 
TSUPB026_23 \\
\end{tabular} & 1520 & 0.38 & 1.120 & 0.230 & 0.0408 & 0.0078 & 0.99 & 0.1954 & 0.0045 & 730.0 & 120.0 & 257.0 & 49.0 & 2786.0 & 38.0 & 90.9 \\
\hline TSUPB026_24 & 760 & 0.29 & 3.080 & 0.610 & 0.1070 & 0.0190 & 0.99 & 0.1956 & 0.0050 & 1400.0 & 140.0 & 690.0 & 130.0 & 2788.0 & 41.0 & 76.6 \\
\hline TSUPB026_25 & 1340 & 0.62 & 0.563 & 0.053 & 0.0206 & 0.0019 & 0.95 & 0.1978 & 0.0082 & 451.0 & 35.0 & 131.0 & 12.0 & 2801.0 & 68.0 & 95.3 \\
\hline TSUPB026_26 & 790 & 0.47 & 2.870 & 0.290 & 0.1060 & 0.0100 & 0.99 & 0.1972 & 0.0034 & 1380.0 & 87.0 & 648.0 & 61.0 & 2802.0 & 28.0 & 77.0 \\
\hline \begin{tabular}{|l|} 
TSUPB026_27 \\
\end{tabular} & 402 & 0.47 & 6.730 & 0.320 & 0.2430 & 0.0140 & 0.93 & 0.1982 & 0.0032 & 2075.0 & 43.0 & 1403.0 & 72.0 & 2811.0 & 26.0 & 49.2 \\
\hline
\end{tabular}




\begin{tabular}{|c|c|c|c|c|c|c|c|c|c|c|c|c|c|c|c|c|}
\hline TSUPB026_28 & 627 & \begin{tabular}{|l|}
0.39 \\
\end{tabular} & 3.780 & 0.340 & 0.1380 & 0.0130 & 0.95 & 0.1986 & 0.0047 & 1582.0 & 70.0 & 833.0 & 75.0 & 2813.0 & 39.0 & 71.3 \\
\hline \begin{tabular}{|l} 
TSUPB026_29 \\
\end{tabular} & 606 & 0.29 & 5.300 & 0.330 & 0.1950 & 0.0110 & 0.75 & 0.1986 & 0.0031 & 1863.0 & 56.0 & 1145.0 & 61.0 & 2814.0 & 25.0 & 59.5 \\
\hline TSUPB026_30 & 2110 & 0.26 & 1.670 & 0.160 & 0.0632 & 0.0059 & 0.97 & 0.1981 & 0.0050 & 1012.0 & 55.0 & 395.0 & 36.0 & 2818.0 & 36.0 & 85.9 \\
\hline TSUPB026_31 & 510 & 0.32 & 1.800 & 0.230 & 0.0659 & 0.0071 & 0.97 & 0.1988 & 0.0078 & 1045.0 & 75.0 & 411.0 & 43.0 & 2822.0 & 60.0 & 85.8 \\
\hline \begin{tabular}{|l|} 
TSUPB026_32 \\
\end{tabular} & 510 & 0.37 & 2.890 & 0.200 & 0.1059 & 0.0068 & 0.94 & 0.1993 & 0.0057 & 1374.0 & 52.0 & 648.0 & 39.0 & 2827.0 & 49.0 & 77.6 \\
\hline \begin{tabular}{|l|} 
TSUPB026_33 \\
\end{tabular} & 260 & 0.41 & 5.340 & 0.450 & 0.1940 & 0.0160 & 0.98 & 0.2009 & 0.0028 & 1844.0 & 76.0 & 1136.0 & 85.0 & 2831.0 & 23.0 & 60.0 \\
\hline TSUPB026_34 & 620 & 0.34 & 5.270 & 0.800 & 0.1890 & 0.0280 & 1.00 & 0.2008 & 0.0028 & 1830.0 & 140.0 & 1110.0 & 150.0 & 2832.0 & 23.0 & 60.9 \\
\hline TSUPB026_35 & 910 & 0.33 & 2.840 & 0.140 & 0.1023 & 0.0056 & 0.92 & 0.2010 & 0.0044 & 1363.0 & 39.0 & 628.0 & 33.0 & 2833.0 & 36.0 & 77.8 \\
\hline TSUPB026_36 & 570 & 0.15 & 5.900 & 0.260 & 0.2121 & 0.0091 & 0.81 & 0.2018 & 0.0031 & 1958.0 & 39.0 & 1239.0 & 48.0 & 2840.0 & 25.0 & 56.3 \\
\hline TSUPB026_37 & 1060 & 0.36 & 1.360 & 0.110 & 0.0481 & 0.0044 & 0.93 & 0.2016 & 0.0065 & 866.0 & 48.0 & 303.0 & 27.0 & 2848.0 & 56.0 & 89.3 \\
\hline \begin{tabular}{|l|} 
TSUPB026_38 \\
\end{tabular} & 562 & 0.84 & 2.720 & 0.200 & 0.0981 & 0.0078 & 0.83 & 0.2037 & 0.0077 & 1340.0 & 59.0 & 603.0 & 46.0 & 2850.0 & 59.0 & 78.7 \\
\hline TSUPB026_39 & 580 & 1.02 & 4.250 & 0.330 & 0.1500 & 0.0094 & 0.96 & 0.2031 & 0.0031 & 1694.0 & 71.0 & 900.0 & 53.0 & 2851.0 & 25.0 & 68.7 \\
\hline TSUPB026_40 & 350 & 0.36 & 8.700 & 1.100 & 0.3130 & 0.0370 & 1.00 & 0.2032 & 0.0017 & 2290.0 & 120.0 & 1780.0 & 170.0 & 2852.0 & 14.0 & 37.8 \\
\hline \begin{tabular}{|l|} 
TSUPB026_41 \\
\end{tabular} & 217 & 0.30 & 7.360 & 0.720 & 0.2600 & 0.0250 & 0.98 & 0.2023 & 0.0034 & 2158.0 & 89.0 & 1480.0 & 130.0 & 2852.0 & 31.0 & 48.1 \\
\hline TSUPB026_42 & 550 & 0.22 & 4.780 & 0.730 & 0.1720 & 0.0260 & 0.99 & 0.2038 & 0.0044 & 1750.0 & 150.0 & 1010.0 & 150.0 & 2862.0 & 33.0 & 64.4 \\
\hline TSUPB026_43 & 650 & 0.22 & 3.330 & 0.240 & 0.1162 & 0.0074 & 0.89 & 0.2052 & 0.0067 & 1481.0 & 55.0 & 708.0 & 43.0 & 2864.0 & 53.0 & 75.3 \\
\hline TSUPB026_44 & 4600 & 0.74 & 0.670 & 0.160 & 0.0239 & 0.0055 & 1.00 & 0.2050 & 0.0030 & 507.0 & 98.0 & 152.0 & 35.0 & 2866.0 & 24.0 & 94.7 \\
\hline TSUPB026_45 & 670 & 0.31 & 7.530 & 0.690 & 0.2690 & 0.0240 & 1.00 & 0.2057 & 0.0015 & 2166.0 & 90.0 & 1530.0 & 120.0 & 2872.0 & 12.0 & 46.6 \\
\hline \begin{tabular}{|l|} 
TSUPB026_46 \\
\end{tabular} & 431 & 0.24 & 6.260 & 0.380 & 0.2220 & 0.0160 & 0.97 & 0.2060 & 0.0039 & 2007.0 & 55.0 & 1292.0 & 83.0 & 2873.0 & 32.0 & 55.6 \\
\hline TSUPB026_47 & 690 & 0.53 & 3.020 & 0.230 & 0.1073 & 0.0075 & 0.95 & 0.2048 & 0.0057 & 1404.0 & 64.0 & 656.0 & 44.0 & 2873.0 & 49.0 & 77.6 \\
\hline TSUPB026_48 & 500 & 0.45 & 7.250 & 0.580 & 0.2540 & 0.0200 & 0.99 & 0.2064 & 0.0033 & 2127.0 & 79.0 & 1450.0 & 110.0 & 2876.0 & 26.0 & 49.4 \\
\hline TSUPB026_49 & 440 & 0.29 & 7.100 & 1.300 & 0.2440 & 0.0370 & 0.98 & 0.2066 & 0.0047 & 2090.0 & 160.0 & 1400.0 & 190.0 & 2878.0 & 37.0 & 51.9 \\
\hline \begin{tabular}{|l|} 
TSUPB026_50 \\
\end{tabular} & 570 & 0.33 & 6.600 & 1.200 & 0.2320 & 0.0390 & 1.00 & 0.2079 & 0.0024 & 2050.0 & 160.0 & 1330.0 & 210.0 & 2889.0 & 19.0 & 54.1 \\
\hline \begin{tabular}{|l|} 
TSUPB026_51 \\
\end{tabular} & 690 & 0.29 & 4.260 & 0.270 & 0.1468 & 0.0091 & 0.97 & 0.2082 & 0.0044 & 1679.0 & 56.0 & 882.0 & 51.0 & 2889.0 & 34.0 & 69.6 \\
\hline \begin{tabular}{|l|} 
TSUPB026_52 \\
\end{tabular} & 309 & 0.22 & 7.480 & 0.740 & 0.2580 & 0.0280 & 0.99 & 0.2074 & 0.0032 & 2148.0 & 96.0 & 1470.0 & 150.0 & 2890.0 & 26.0 & 49.0 \\
\hline \begin{tabular}{|l|} 
TSUPB026_53 \\
\end{tabular} & 860 & 0.30 & 5.200 & 0.680 & 0.1820 & 0.0230 & 0.99 & 0.2084 & 0.0040 & 1800.0 & 150.0 & 1070.0 & 130.0 & 2891.0 & 31.0 & 62.9 \\
\hline TSUPB026_54 & 420 & 0.54 & 9.160 & 0.790 & 0.3200 & 0.0280 & 0.98 & 0.2087 & 0.0047 & 2344.0 & 84.0 & 1790.0 & 140.0 & 2894.0 & 37.0 & 39.8 \\
\hline \begin{tabular}{|l|l|} 
TSUPB026_55 \\
\end{tabular} & 263 & 0.64 & 8.610 & 0.370 & 0.2990 & 0.0100 & 0.94 & 0.2089 & 0.0034 & 2294.0 & 40.0 & 1688.0 & 50.0 & 2896.0 & 26.0 & 41.8 \\
\hline TSUPB026_56 & 401 & 0.45 & 7.430 & 0.910 & 0.2560 & 0.0320 & 0.99 & 0.2091 & 0.0031 & 2150.0 & 120.0 & 1460.0 & 160.0 & 2898.0 & 24.0 & 49.4 \\
\hline TSUPB026_57 & 410 & 0.60 & 6.500 & 1.500 & 0.2310 & 0.0500 & 1.00 & 0.2093 & 0.0057 & 2010.0 & 210.0 & 1330.0 & 260.0 & 2899.0 & 45.0 & 54.1 \\
\hline TSUPB026_58 & 413 & 0.36 & 10.560 & 0.260 & 0.3695 & 0.0089 & 0.96 & 0.2097 & 0.0028 & 2492.0 & 28.0 & 2041.0 & 50.0 & 2902.0 & 22.0 & 29.5 \\
\hline TSUPB026_59 & 989 & 0.42 & 2.485 & 0.082 & 0.0850 & 0.0032 & 0.57 & 0.2098 & 0.0049 & 1267.0 & 24.0 & 526.0 & 19.0 & 2902.0 & 37.0 & 81.9 \\
\hline \begin{tabular}{|l|} 
TSUPB026_60 \\
\end{tabular} & 533 & 0.16 & 9.340 & 0.310 & 0.3250 & 0.0120 & 0.96 & 0.2098 & 0.0017 & 2371.0 & 31.0 & 1813.0 & 58.0 & 2904.0 & 13.0 & 38.1 \\
\hline \begin{tabular}{|l|} 
TSUPB026_61 \\
\end{tabular} & 290 & 0.42 & 9.000 & 0.530 & 0.3110 & 0.0170 & 0.97 & 0.2103 & 0.0037 & 2330.0 & 59.0 & 1741.0 & 84.0 & 2906.0 & 29.0 & 40.2 \\
\hline \begin{tabular}{|l|} 
TSUPB026_62 \\
\end{tabular} & 220 & 0.41 & 4.560 & 0.390 & 0.1590 & 0.0140 & 0.95 & 0.2103 & 0.0043 & 1730.0 & 73.0 & 951.0 & 77.0 & 2906.0 & 33.0 & 67.7 \\
\hline \begin{tabular}{|l} 
TSUPB026_63 \\
\end{tabular} & 261 & 0.31 & 13.040 & 0.840 & 0.4460 & 0.0300 & 0.98 & 0.2104 & 0.0040 & 2672.0 & 67.0 & 2370.0 & 140.0 & 2907.0 & 31.0 & 18.5 \\
\hline \begin{tabular}{|l|} 
TSUPB026_64 \\
\end{tabular} & 419 & 0.25 & 6.570 & 0.440 & 0.2290 & 0.0150 & 0.98 & 0.2103 & 0.0036 & 2048.0 & 60.0 & 1329.0 & 81.0 & 2907.0 & 28.0 & 55.1 \\
\hline TSUPB026_65 & 380 & 0.44 & 6.000 & 0.760 & 0.2080 & 0.0240 & 0.99 & 0.2108 & 0.0049 & 1970.0 & 120.0 & 1210.0 & 130.0 & 2909.0 & 37.0 & 58.5 \\
\hline \begin{tabular}{|l} 
TSUPB026_66 \\
\end{tabular} & 325 & 0.42 & 8.500 & 1.800 & 0.2980 & 0.0560 & 1.00 & 0.2107 & 0.0062 & 2260.0 & 200.0 & 1670.0 & 280.0 & 2910.0 & 47.0 & 42.7 \\
\hline TSUPB026_67 & 112 & 0.51 & 9.170 & 0.280 & 0.3049 & 0.0078 & 0.74 & 0.2110 & 0.0038 & 2354.0 & 28.0 & 1715.0 & 39.0 & 2913.0 & 29.0 & 41.4 \\
\hline \begin{tabular}{|l} 
TSUPB026_68 \\
\end{tabular} & 700 & 0.37 & 2.340 & 0.160 & 0.0802 & 0.0044 & 0.94 & 0.2108 & 0.0040 & 1232.0 & 50.0 & 497.0 & 26.0 & 2918.0 & 27.0 & 83.0 \\
\hline \begin{tabular}{|l|} 
TSUPB026_69 \\
\end{tabular} & 301 & 0.31 & 8.510 & 0.420 & 0.2950 & 0.0120 & 0.87 & 0.2120 & 0.0048 & 2282.0 & 46.0 & 1666.0 & 58.0 & 2919.0 & 37.0 & 42.6 \\
\hline
\end{tabular}




\begin{tabular}{|c|c|c|c|c|c|c|c|c|c|c|c|c|c|c|c|c|}
\hline \begin{tabular}{|l|} 
TSUPB026_70 \\
\end{tabular} & 389 & 0.32 & 9.820 & 0.470 & 0.3420 & 0.0130 & 0.98 & 0.2121 & 0.0028 & 2414.0 & 46.0 & 1897.0 & 65.0 & 2921.0 & 21.0 & 34.6 \\
\hline TSUPB026_71 & 458 & 0.64 & 6.670 & 0.570 & 0.2210 & 0.0220 & 0.97 & 0.2125 & 0.0064 & 2055.0 & 79.0 & 1310.0 & 110.0 & 2921.0 & 49.0 & 58.2 \\
\hline TSUPB026_72 & 362 & 1.08 & 4.560 & 0.470 & 0.1580 & 0.0150 & 0.99 & 0.2125 & 0.0029 & 1713.0 & 87.0 & 938.0 & 84.0 & 2923.0 & 22.0 & 68.0 \\
\hline TSUPB026_73 & 204 & 0.44 & 15.100 & 1.100 & 0.5110 & 0.0390 & 0.90 & 0.2135 & 0.0080 & 2808.0 & 73.0 & 2650.0 & 170.0 & 2925.0 & 63.0 & 9.3 \\
\hline \begin{tabular}{|l|} 
TSUPB026_74 \\
\end{tabular} & 537 & 0.40 & 5.800 & 0.250 & 0.1980 & 0.0085 & 0.94 & 0.2130 & 0.0035 & 1944.0 & 37.0 & 1164.0 & 46.0 & 2927.0 & 26.0 & 60.4 \\
\hline \begin{tabular}{|l} 
TSUPB026_75 \\
\end{tabular} & 509 & 0.50 & 4.820 & 0.170 & 0.1641 & 0.0066 & 0.88 & 0.2130 & 0.0045 & 1787.0 & 31.0 & 979.0 & 37.0 & 2927.0 & 34.0 & 66.6 \\
\hline TSUPB026_76 & 299 & 0.33 & 12.820 & 0.410 & 0.4310 & 0.0140 & 0.92 & 0.2133 & 0.0037 & 2665.0 & 31.0 & 2311.0 & 66.0 & 2930.0 & 28.0 & 22.0 \\
\hline TSUPB026_77 & 480 & 0.51 & 9.700 & 1.600 & 0.3390 & 0.0540 & 1.00 & 0.2138 & 0.0025 & 2420.0 & 150.0 & 1860.0 & 270.0 & 2934.0 & 19.0 & 36.3 \\
\hline TSUPB026_78 & 319 & 0.37 & 8.720 & 0.890 & 0.3060 & 0.0320 & 0.96 & 0.2140 & 0.0046 & 2360.0 & 68.0 & 1710.0 & 160.0 & 2934.0 & 34.0 & 41.1 \\
\hline \begin{tabular}{|l|} 
TSUPB026_79 \\
\end{tabular} & 70 & 0.47 & 14.560 & 0.620 & 0.5060 & 0.0190 & 0.88 & 0.2140 & 0.0039 & 2785.0 & 40.0 & 2640.0 & 82.0 & 2935.0 & 30.0 & 8.5 \\
\hline \begin{tabular}{|l} 
TSUPB026_80 \\
\end{tabular} & 338 & 0.44 & 8.900 & 0.980 & 0.3080 & 0.0350 & 0.97 & 0.2144 & 0.0064 & 2300.0 & 120.0 & 1720.0 & 180.0 & 2935.0 & 48.0 & 40.8 \\
\hline TSUPB026_81 & 420 & 0.50 & 9.010 & 0.510 & 0.3030 & 0.0150 & 0.98 & 0.2144 & 0.0036 & 2332.0 & 56.0 & 1703.0 & 77.0 & 2937.0 & 27.0 & 43.2 \\
\hline TSUPB026_82 & 266 & 0.70 & 14.250 & 0.800 & 0.4840 & 0.0240 & 0.99 & 0.2144 & 0.0026 & 2758.0 & 57.0 & 2540.0 & 110.0 & 2938.0 & 20.0 & 13.7 \\
\hline TSUPB026_83 & 248 & 0.25 & 8.520 & 0.720 & 0.2920 & 0.0230 & 0.97 & 0.2144 & 0.0043 & 2275.0 & 82.0 & 1640.0 & 120.0 & 2938.0 & 33.0 & 43.8 \\
\hline TSUPB026_84 & 172 & 0.32 & 13.620 & 0.670 & 0.4680 & 0.0200 & 0.96 & 0.2145 & 0.0022 & 2720.0 & 47.0 & 2471.0 & 86.0 & 2939.0 & 17.0 & 15.7 \\
\hline TSUPB026_85 & 175 & 0.43 & 11.630 & 0.530 & 0.3950 & 0.0170 & 0.96 & 0.2146 & 0.0033 & 2571.0 & 44.0 & 2142.0 & 78.0 & 2940.0 & 25.0 & 27.2 \\
\hline TSUPB026_86 & 189 & 0.87 & 7.720 & 0.270 & 0.2605 & 0.0099 & 0.97 & 0.2146 & 0.0022 & 2194.0 & 33.0 & 1490.0 & 51.0 & 2946.0 & 15.0 & 49.2 \\
\hline TSUPB026_87 & 463 & 0.45 & 9.500 & 1.300 & 0.3100 & 0.0340 & 0.98 & 0.2159 & 0.0018 & 2370.0 & 120.0 & 1830.0 & 240.0 & 2950.0 & 13.0 & 41.1 \\
\hline \begin{tabular}{|l|} 
TSUPB026_88 \\
\end{tabular} & 500 & 0.31 & 9.500 & 2.100 & 0.3350 & 0.0780 & 1.00 & 0.2160 & 0.0064 & 2370.0 & 210.0 & 1850.0 & 380.0 & 2951.0 & 47.0 & 37.0 \\
\hline \begin{tabular}{|l|} 
TSUPB026_89 \\
\end{tabular} & 183 & 0.35 & 17.060 & 0.690 & 0.5770 & 0.0200 & 0.95 & 0.2169 & 0.0036 & 2935.0 & 40.0 & 2932.0 & 84.0 & 2956.0 & 27.0 & 1.0 \\
\hline TSUPB026_90 & 500 & 0.29 & 6.450 & 0.440 & 0.2180 & 0.0140 & 0.96 & 0.2170 & 0.0051 & 2032.0 & 62.0 & 1271.0 & 75.0 & 2956.0 & 37.0 & 57.0 \\
\hline TSUPB026_91 & 354 & 0.18 & 11.290 & 0.900 & 0.3820 & 0.0320 & 0.98 & 0.2170 & 0.0035 & 2535.0 & 78.0 & 2080.0 & 150.0 & 2957.0 & 26.0 & 29.4 \\
\hline TSUPB026_92 & 189 & 0.40 & 13.400 & 1.100 & 0.4540 & 0.0250 & 0.97 & 0.2174 & 0.0045 & 2691.0 & 81.0 & 2410.0 & 110.0 & 2960.0 & 33.0 & 19.1 \\
\hline \begin{tabular}{|l|} 
TSUPB026_93 \\
\end{tabular} & 352 & 0.34 & 12.420 & 0.430 & 0.4160 & 0.0170 & 0.95 & 0.2174 & 0.0028 & 2634.0 & 33.0 & 2240.0 & 79.0 & 2961.0 & 21.0 & 24.5 \\
\hline \begin{tabular}{|l|} 
TSUPB026_94 \\
\end{tabular} & 576 & 0.44 & 4.370 & 0.310 & 0.1490 & 0.0130 & 0.95 & 0.2180 & 0.0092 & 1702.0 & 56.0 & 892.0 & 75.0 & 2961.0 & 67.0 & 69.7 \\
\hline \begin{tabular}{|l|} 
TSUPB026_95 \\
\end{tabular} & 156 & 0.25 & 17.530 & 0.930 & 0.5850 & 0.0260 & 0.97 & 0.2179 & 0.0042 & 2958.0 & 54.0 & 2970.0 & 110.0 & 2964.0 & 31.0 & -0.3 \\
\hline TSUPB026_96 & 168 & 0.25 & 16.400 & 1.000 & 0.5540 & 0.0260 & 0.98 & 0.2180 & 0.0029 & 2890.0 & 66.0 & 2840.0 & 110.0 & 2965.0 & 21.0 & 4.6 \\
\hline \begin{tabular}{|l|} 
TSUPB026_97 \\
\end{tabular} & 583 & 0.30 & 4.420 & 0.180 & 0.1457 & 0.0058 & 0.80 & 0.2196 & 0.0063 & 1714.0 & 35.0 & 876.0 & 32.0 & 2976.0 & 46.0 & 70.1 \\
\hline \begin{tabular}{|l|} 
TSUPB026_98 \\
\end{tabular} & 248 & 0.51 & 13.430 & 0.550 & 0.4330 & 0.0210 & 0.98 & 0.2205 & 0.0036 & 2707.0 & 40.0 & 2316.0 & 94.0 & 2983.0 & 26.0 & 22.8 \\
\hline TSUPB026_99 & 167 & 0.35 & 17.620 & 0.380 & 0.5850 & 0.0160 & 0.94 & 0.2211 & 0.0027 & 2969.0 & 21.0 & 2970.0 & 64.0 & 2988.0 & 20.0 & 0.1 \\
\hline TSUPB026_100 & 249 & 0.50 & 14.370 & 0.440 & 0.4640 & 0.0120 & 0.68 & 0.2229 & 0.0056 & 2773.0 & 29.0 & 2456.0 & 55.0 & 3012.0 & 36.0 & 18.4 \\
\hline TSUPB026_101 & 524 & 0.17 & 3.550 & 0.260 & 0.1133 & 0.0090 & 0.94 & 0.2248 & 0.0056 & 1534.0 & 58.0 & 692.0 & 52.0 & 3014.0 & 40.0 & 77.0 \\
\hline \begin{tabular}{|l} 
TSUPB026_102 \\
\end{tabular} & 840 & 0.59 & 9.100 & 1.200 & 0.2940 & 0.0390 & 0.98 & 0.2250 & 0.0044 & 2370.0 & 130.0 & 1640.0 & 200.0 & 3015.0 & 31.0 & 45.7 \\
\hline \begin{tabular}{|l|} 
TSUPB026_103 \\
\end{tabular} & 221 & 0.41 & 13.990 & 0.470 & 0.4580 & 0.0150 & 0.92 & 0.2254 & 0.0034 & 2747.0 & 32.0 & 2430.0 & 68.0 & 3019.0 & 24.0 & 19.9 \\
\hline \begin{tabular}{|l} 
TSUPB026_104 \\
\end{tabular} & 287 & 0.51 & 15.820 & 0.610 & 0.4970 & 0.0230 & 0.89 & 0.2280 & 0.0051 & 2864.0 & 38.0 & 2622.0 & 91.0 & 3036.0 & 36.0 & 14.6 \\
\hline & & & & & & & & & & & & & & & & \\
\hline \begin{tabular}{|l} 
TSUPB026_Rim_1 \\
\end{tabular} & 22900 & 0.51 & 0.045 & 0.006 & 0.0024 & 0.0004 & 0.97 & 0.1434 & 0.0069 & 44.7 & 6.0 & 15.6 & 2.8 & 2268.0 & 83.0 & 99.3 \\
\hline TSUPB026_Rim_2 & 29000 & 0.46 & 0.033 & 0.006 & 0.0018 & 0.0005 & 0.90 & 0.1440 & 0.0150 & 33.1 & 5.4 & 11.5 & 3.0 & 2280.0 & 180.0 & 99.5 \\
\hline TSUPB026_Rim_3 & 16900 & 0.47 & 0.072 & 0.019 & 0.0036 & 0.0010 & 0.99 & 0.1541 & 0.0062 & 71.0 & 18.0 & 22.9 & 6.3 & 2392.0 & 68.0 & 99.0 \\
\hline TSUPB026_Rim_4 & 9600 & 0.46 & 0.124 & 0.022 & 0.0055 & 0.0007 & 1.00 & 0.1701 & 0.0069 & 119.0 & 20.0 & 35.3 & 4.7 & 2557.0 & 68.0 & 98.6 \\
\hline \begin{tabular}{|l} 
TSUPB026_Rim_5 \\
\end{tabular} & 6900 & 0.45 & 0.161 & 0.018 & 0.0070 & 0.0010 & 0.83 & 0.1720 & 0.0200 & 151.0 & 15.0 & 45.1 & 6.4 & 2570.0 & 200.0 & 98.2 \\
\hline
\end{tabular}




\begin{tabular}{|c|c|c|c|c|c|c|c|c|c|c|c|c|c|c|c|c|}
\hline TSUPB026_Rim_6 & 4060 & 0.47 & 0.255 & 0.045 & 0.0103 & 0.0020 & 0.99 & 0.1847 & 0.0088 & 230.0 & 37.0 & 66.0 & 12.0 & 2694.0 & 79.0 & 97.6 \\
\hline TSUPB026_Rim_7 & 1970 & 0.51 & 0.307 & 0.010 & 0.0120 & 0.0004 & 0.74 & 0.1870 & 0.0130 & 272.1 & 7.5 & 77.0 & 2.8 & 2710.0 & 110.0 & 97.2 \\
\hline TSUPB026_Rim_8 & 1850 & 0.52 & 0.356 & 0.047 & 0.0137 & 0.0020 & 0.91 & 0.1905 & 0.0076 & 309.0 & 35.0 & 88.0 & 13.0 & 2746.0 & 65.0 & 96.8 \\
\hline TSUPB026_Rim_9 & 2273 & 0.56 & 0.375 & 0.034 & 0.0144 & 0.0018 & 0.18 & 0.1950 & 0.0360 & 323.0 & 25.0 & 92.0 & 12.0 & 2760.0 & 320.0 & 96.6 \\
\hline TSUPB026_Rim_10 & 2970 & 0.52 & 0.317 & 0.008 & 0.0122 & 0.0001 & 1.00 & 0.1924 & 0.0033 & 279.3 & 6.2 & 78.1 & 0.5 & 2762.0 & 28.0 & 97.2 \\
\hline TSUPB026_Rim_11 & 2170 & 0.50 & 0.380 & 0.049 & 0.0143 & 0.0014 & 0.78 & 0.1952 & 0.0057 & 327.0 & 36.0 & 91.5 & 9.0 & 2786.0 & 48.0 & 96.7 \\
\hline TSUPB026_Rim_12 & 1750 & 0.61 & 0.426 & 0.042 & 0.0160 & 0.0030 & 1.00 & 0.1960 & 0.0170 & 360.0 & 30.0 & 102.0 & 19.0 & 2790.0 & 140.0 & 96.3 \\
\hline
\end{tabular}

